\title{
Loopbanen van leerlingen van Administratieve Opleidingen
}

Citation for published version (APA):

Meng, C., \& de Lombaerde, G. (2019). Loopbanen van leerlingen van Administratieve Opleidingen. ROA. ROA Reports No. 005 https://doi.org/10.26481/umarep.2019005

Document status and date:

Published: 27/09/2019

DOI:

10.26481/umarep.2019005

Document Version:

Publisher's PDF, also known as Version of record

\section{Please check the document version of this publication:}

- A submitted manuscript is the version of the article upon submission and before peer-review. There can be important differences between the submitted version and the official published version of record.

People interested in the research are advised to contact the author for the final version of the publication, or visit the DOI to the publisher's website.

- The final author version and the galley proof are versions of the publication after peer review.

- The final published version features the final layout of the paper including the volume, issue and page numbers.

Link to publication

\footnotetext{
General rights rights.

- You may freely distribute the URL identifying the publication in the public portal. please follow below link for the End User Agreement:

www.umlib.nl/taverne-license

Take down policy

If you believe that this document breaches copyright please contact us at:

repository@maastrichtuniversity.nl

providing details and we will investigate your claim.
}

Copyright and moral rights for the publications made accessible in the public portal are retained by the authors and/or other copyright owners and it is a condition of accessing publications that users recognise and abide by the legal requirements associated with these

- Users may download and print one copy of any publication from the public portal for the purpose of private study or research.

- You may not further distribute the material or use it for any profit-making activity or commercial gain

If the publication is distributed under the terms of Article $25 \mathrm{fa}$ of the Dutch Copyright Act, indicated by the "Taverne" license above, 
Maastricht University

\section{Loopbanen van leerlingen van Administratieve Opleidingen}

Christoph Meng

Griet de Lombaerde

\section{ROA Rapport}

ROA-R-2019/5

Researchcentrum voor Onderwijs en Arbeidsmarkt | ROA Research Centre for Education and the Labour Market / ROA 


\section{Colofon}

(C) Researchcentrum voor Onderwijs en Arbeidsmarkt (ROA). Niets uit deze uitgave mag op enige manier worden verveelvoudigd zonder voorafgaande schriftelijke toestemming van de directeur van het ROA.

\section{Researchcentrum voor Onderwijs en Arbeidsmarkt}

Postbus 616

6200 MD Maastricht

$\mathrm{T}+31433883647$

$\mathrm{F}+31433884914$

secretary-roa-sbe@maastrichtuniversity.nl

www.roa.nl

School of Business and Economics

Maastricht University

\section{Vormgeving}

ROA secretariaat, Maastricht

ISBN: 978-90-5321-579-1

mei 2019 


\section{INHOUD}

1 inleiding

2 Data

2.1 DUO-gegevens 3

2.2 BVE-monitor 4

2.3 HBO-Monitor 4

2.4 ArbeidsmarktInformatieSysteem (AIS) 5

2.5 CBS-Data 5

3 Vmbo basisberoepsgerichte leerweg 7

3.1 Het derde leerjaar 7

3.2 Van het derde leerjaar vmbo BB naar het mbo 10

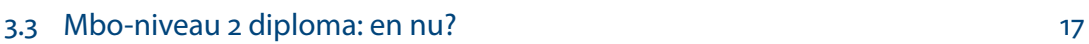

4 Vmbo kaderberoepsgerichte leerweg $\quad 21$

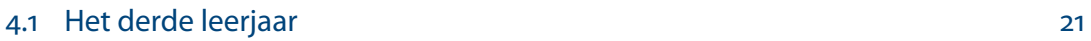

4.2 Van het derde leerjaar vmbo KB naar het mbo 24

$5 \quad$ Vmbo gemengde en theoretische leerweg 33

$\begin{array}{ll}5.1 \text { Het derde leerjaar } & 33\end{array}$

$\begin{array}{ll}\text { 5.2 Van vmbo GL/TL naar mbo } & 34\end{array}$

6 Mbo-niveau 4 diploma: doorstroom naar hbo 39

7 Arbeidsmarktrelevantie $\quad 43$

7.1 Arbeidsmarkt van mbo-gediplomeerden: Het vinden van werk 43

7.2 Arbeidsmarkt van mbo-gediplomeerden: Aanvullende indicatoren 45

7.3 Hbo-gediplomeerde leerlingen: HBO-Monitor 51

7.4 Arbeidsmarktprognoses $\quad 52$

$\begin{array}{ll}\text { Statistische Bijlage } & 55\end{array}$ 


\section{INLEIDING}

Administratieve opleidingen zijn in zowel het vmbo als het mbo een belangrijk onderdeel. Een significant deel van de jongeren, en zeker onder de groep met een niet-westerse migratieachtergrond, kiest voor deze opleidingen. In opdracht van de Commissie Macrodoelmatigheid MBO (CMMBO) heeft het Researchcentrum voor Onderwijs en Arbeidsmarkt (ROA) een onderzoek uitgevoerd om de profielen van jongeren die een administratieve opleiding volgen, de vervolgstappen van jongeren die in het vmbo een administratieve opleiding volgen, en de arbeidsmarktrelevantie administratieve beroepsopleidingen in het mbo, te achterhalen. Onder de administratieve vmbo-opleidingen verstaan we in dit rapport opleidingen die onder de sector Economie vallen. Onder de administratieve mbo-beroepsopleidingen verstaan we de beroepsopleidingen die onder twee domeinen vallen, namelijk Economie en Administratie en Handel en Ondernemerschap. De opzet van het onderzoek is vergelijkbaar met de eerdere onderzoeken naar creatieve beroepsopleidingen in het mbo alsook mbo-niveau 2 beroepsopleidingen. Daarbij staat in het voorliggende rapport echter, zowel de doorstroom naar een vervolgopleiding als het behalen van een diploma in het vervolgonderwijs centraal, en speelt de vraag naar de arbeidsmarktrelevantie een ondergeschikte rol.

De opbouw van het voorliggende rapport is als volgt. In Paragraaf 2 presenteren we kort de data waarop de analyses in dit rapport zijn gebaseerd. In Paragraaf 3 staan we stil bij de jongeren die in het derde leerjaar van de basisberoepsgerichte leerweg (vmbo BB) zitten. We bespreken kort de samenstelling van deze groep jongeren met betrekking tot de vmbo-sectoren, het hebben van leerwegondersteuning (LWOO), geslacht alsmede etnische achtergrond. Daarna staan we stil bij hun weg door het vmbo tot het behalen van het mbo-niveau 2 diploma. Tot slot, stellen we de vraag wat de jongeren na het behalen van het mbo-niveau 2 diploma doen. Stromen ze door naar een hogere mbo-opleiding of verlaten ze het mbo? Indien ze doorstromen, blijven ze dan binnen het mbo-domein waarin ze het niveau 2 diploma behaald hebben, of wisselen ze van domein, en zo ja, welk niveau van mbo-domein behalen ze daarna?

In Paragraaf 4 en 5 staan we stil bij de vmbo-leerwegen die in principe voorbereiden op instroom in een mbo-niveau 3 of mbo-niveau 4 domein, namelijk de kaderberoepsgerichte leerweg (vmbo KB), en de gemengde en theoretische leerweg (vmbo GL/TL). We bespreken wederom eerst per leerweg de samenstelling van de groep jongeren in het 
derde leerjaar (naar sectoren, LWOO, geslacht en etnische achtergrond). Daarna staan we stil bij hun weg naar de mbo-opleiding, analyseren welk type opleiding ze in het mbo volgen en welk diploma ze behalen.

In Paragraaf 6 analyseren we de groep jongeren die een mbo-niveau 4 diploma heeft behaald, en kijken we in hoeverre zij in de vervolgjaren een diploma in het hoger onderwijs behalen en in hoeverre ze dit doen in een sector van het hoger onderwijs die in het verlengde van hun mbo-domein ligt.

In Paragraaf 7 presenteren we een aantal arbeidsmarktindicatoren op basis van de BVE-Monitor, HBO-Monitor en data afkomstig van het CBS. Ook maken we gebruik van het ArbeidsmarktInformatieSysteem (AIS) van het ROA. Op geaggregeerd niveau bespreken we de arbeidsmarktprognoses tot 2022. 


\section{DATA}

De kwantitatieve analyses in dit rapport zijn uitgevoerd op basis van een vijftal databestanden:

- Onderwijsloopbanen: DUO-gegevens

- Profielen van leerlingen: CBS-data

- Arbeidsmarkt van administratieve opleidingen:

- BVE-Monitor van het ROA/CBS

- HBO-Monitor van het ROA

- Arbeidsmarktinformatiesysteem van het ROA

- Koppeling polisadministratie van UWV, DUO-gegevens en Sociaal Statistisch Bestand (CBS)

Navolgend bespreken we kort deze drie databestanden, en geven we een overzicht van de gemaakte selecties en de eventueel daaraan verbonden afbakeningen.

\subsection{DUO-gegevens}

De informatie over de onderwijsloopbanen van jongeren in administratieve opleidingen, namelijk het volgen van een vervolgopleiding en het eventueel behalen van een diploma voor deze vervolgopleiding, is afkomstig van de Dienst Uitvoering Onderwijs (DUO). Deze data bieden de mogelijkheid om leerlingencohorten te volgen doorheen de tijd, en vast te stellen welke wegen zij in het onderwijs bewandelen. In het kader van het voorliggende onderzoek is daarbij een bestand geanalyseerd waarin een drietal verschillende groepen gevolgd worden in het onderwijs:

1. Leerlingen die in het derde leerjaar van het vmbo ingeschreven staan

2. Gediplomeerden van het mbo-niveau 2

3. Gediplomeerden van het mbo-niveau 4

Wat de eerste groep betreft, de leerlingen die in het derde leerjaar van het vmbo ingeschreven staan, omvatten de data die we analyseren hun verdere onderwijsloopbaan tot en met de inschrijving in het schooljaar 2018-2019. Het eerste cohort dat we daarbij volgen, is het cohort dat in het schooljaar 2010-2011 in het derde leerjaar zat. Het meest recente cohort dat we kunnen volgen, zijn de leerlingen die in het schooljaar 2015-2016 
in het derde leerjaar van het vmbo zaten. Van deze groep leerlingen kunnen we dan ook vaststellen welke mbo-vervolgopleiding zij na het behalen van het vmbo-diploma volg(d)en, in hoeverre deze vervolgopleiding in het verlengde van de vmbo-sector ligt die ze afgerond hebben, en bijvoorbeeld in hoeverre ze in de eerstvolgende jaren een mbo-diploma behaald hebben.

Wat de tweede en derde groep betreft, de groep die een mbo-diploma behaald heeft, zullen we vooral nagaan in hoeverre zij na het behalen van het mbo-diploma een diploma op hoger niveau (zij het in het mbo dan wel in het hoger onderwijs) behaald hebben, en of de vervolgopleiding in het verlengde van de afgeronde opleiding ligt. Voor deze groep gebruiken we de datagegevens van gediplomeerden van de schooljaren 2012-2013 en wederom tot en met de inschrijving in het schooljaar 2018-2019.

\subsection{BVE-monitor}

De BVE-Monitor is het jaarlijkse onderzoek onder de gediplomeerden van het mbo dat sinds begin de jaren negentig door het Researchcentrum voor Onderwijs en Arbeidsmarkt uitgevoerd wordt. Sinds 2016 wordt dit onderzoek gerealiseerd in samenwerking met het CBS. In het kader van de BVE-Monitor worden de gediplomeerden van het mbo (bol en bbl) ongeveer anderhalf jaar na afstuderen bevraagd over hun arbeidsmarktsituatie en hun ervaringen in het vervolgonderwijs. De analyses in dit rapport hebben betrekking op de metingen 2014-2017, ofwel vier jaargangen. Het eerste cohort betreft de gediplomeerde mbo'ers van het schooljaar 2012-2013 (meting 2014), en het laatste cohort betreft de gediplomeerde mbo'ers van het schooljaar 2015-2016 (meting 2017). Op basis van de BVE-Monitor wordt de arbeidsmarkt van gediplomeerden van administratieve opleidingen in het mbo kort in kaart gebracht. We stellen voor om dit op basis van de volgende indicatoren te doen:

- Werkloosheid (1 uur grens en 12 uur grens)

- Werkzaam op niveau

- Werkzaam binnen het eigen opleidingsdomein

- Algemene aansluiting tussen onderwijs en gevonden functie

- Spijt van gevolgde opleiding

\subsection{HBO-Monitor}

De HBO-Monitor is een jaarlijks onderzoek onder de hbo-afgestudeerden dat inzicht geeft in de arbeidsmarktpositie van hbo-afgestudeerden en hoe deze opleidingen aansluiten op de eisen in de beroepspraktijk. In het kader van de HBO-Monitor worden de hbo-afgestudeerden (bachelor, Ad en master) ongeveer anderhalf jaar na het behalen van hun diploma gevraagd om aan een enquête deel te nemen. In het voorliggende onderzoek stellen we voor om de meetjaren 2014 tot en met 2017 samen te nemen. Het betreft dan de afgestudeerden van de studiejaren 2012-2013 tot en met 2015-2016. Op basis van de HBO-Monitor wordt de arbeidsmarkt van afgestudeerden van admini- 
stratieve hbo-opleidingen kort in kaart gebracht. We stellen voor om dit op basis van volgende indicatoren te doen:

- Werkloosheid (1 uur grens en 12 uur grens)

- Werkzaam op niveau

- Werkzaam binnen het eigen opleidingsdomein

- Algemene aansluiting tussen onderwijs en gevonden functie

- Spijt van gevolgde opleiding

\subsection{ArbeidsmarktInformatieSysteem (AIS)}

Het AIS is het ArbeidsmarktInformatieSysteem van het ROA dat in het kader van het Project-Onderwijs-Arbeidsmarkt centrale arbeidsmarktinformatie bevat. Het belangrijkste onderdeel hiervan, en van belang in het kader van het voorliggende onderzoek, zijn de verwachte arbeidsmarktprognoses naar opleiding en beroep tot 2022. We stellen voor om, zover mogelijk, de volgende informatie op te nemen':

- Verwachte uitbreidingsvraag tot 2022

- Verwachte vervangingsvraag tot 2022

- Verwachte baanopeningen tot 2022

- Verwachte uitstroom van gediplomeerden naar arbeidsmarkt

- Toekomstige arbeidsmarktsituatie indicator (ITA) in 2022

\subsection{CBS-Data}

De vijfde informatiebron die we in het voorliggende rapport gebruiken, is de CBS-maatwerktabel over de arbeidsmarktpositie van mbo-schoolverlaters voor de schooljaren 2012/2013 - 2014/2015, een jaar na afstuderen. Deze maatwerktabel biedt voor de jongeren die het mbo verlaten de volgende informatie, die voor dit rapport relevant is; het aantal jongeren dat één jaar na het behalen van hun diploma minimaal 12 uur werkzaam is.

Wat deze cijfers betreft, is het belangrijk om de lezer hier alvast op een aantal verschillen te wijzen in vergelijking tot de berekening van de BVE-Monitor cijfers die in dit rapport centraal staan:

- Werkzaam zijn voor minder dan 12 uur is in de regel sterk gecorreleerd met werkloosheid. Deze correlatie dient echter niet één te zijn, aangezien jongeren die zich uit de arbeidsmarkt terugtrekken (zij het door ziekte, handicap, andere persoonlijke redenen of omdat ze het gevoel hebben geen werk te kunnen vinden), weliswaar worden meegeteld bij het aantal jongeren dat minder dan 12 uur werkzaam is (CBS), maar niet tot de werkloze beroepsbevolking (BVE-Monitor) worden gerekend.

$1 \quad$ Het is belangrijk op te merken dat deze informatie uit het AIS niet per beroepsopleiding beschikbaar is, maar per opleidingscluster. 
- Jongeren die in het niet-bekostigde onderwijs een vervolgopleiding volgen, worden in de BVE-Monitor bij de doorstromers in het onderwijs gerekend. Het CBS kan deze vervolgopleidingen echter niet in kaart brengen en rekent deze personen daarom bij de groep jongeren die het mbo hebben verlaten. Dit geldt ook voor jongeren die een vervolgopleiding in het buitenland volgen maar tegelijk in Nederland woonachtig zijn. 


\section{VMBO BASISBEROEPSGERICHTE LEERWEG}

In dit hoofdstuk staan we stil bij de jongeren die in het derde leerjaar van de basisberoepsgerichte leerweg van het vmbo (vmbo BB) zitten (Paragraaf 3.1). We laten eerst de ontwikkeling zien van het aantal jongeren in de onderzochte periode, bespreken welk deel van de jongeren de vmbo-opleiding in de sector Economie volgt (de sector die centraal staat in dit rapport), en identificeren de jongeren op basis van een aantal persoonlijke en opleidingsgerelateerde kenmerken (geslacht, etnische achtergrond, leerwegondersteuning). In Paragraaf 3.2 volgen we de jongeren bij hun instroom in het mbo en laten we zien in hoeverre zij daar succesvol zijn. Tot slot analyseren we in Paragraaf 3.3 de gediplomeerden van het mbo-niveau 2, het mbo-niveau waarvoor de vmbo basisberoepsgerichte leerweg in eerste instantie voorbereidt.

\subsection{Het derde leerjaar}

Figuur 3.1 laat het aantal leerlingen in het derde leerjaar van de vmbo BB zien voor de schooljaren 2010-2011 tot en met 2015-2016. We presenteren daarbij zowel de cijfers voor de totale groep die in het derde leerjaar zit, als de groep die in een opleiding in de economische sector van de vmbo BB zit. Het aantal leerlingen in het derde leerjaar varieert tussen 20.881 (cohort 2013) en 22.700 (cohort 2015), het aantal leerlingen in de sector Economie varieert tussen 3470 (cohort 2014) en 4875 (cohort 2010). Over het algemeen kan voor het vmbo BB (met uitzondering van het schooljaar 2015-2016) een lichte daling in het aantal leerlingen in het derde leerjaar vastgesteld worden. In dezelfde periode zien we dat het aantal leerlingen dat in de sector Economie de opleiding volgt met zo'n 20\% daalt. Dat deze daling tot een duidelijk kleiner aandeel leerlingen in de sector Economie over de tijd leidt, wordt duidelijk in Tabel 3.1. 
FIGUUR 3.1 Aantal leerlingen in het derde leerjaar vmbo BB

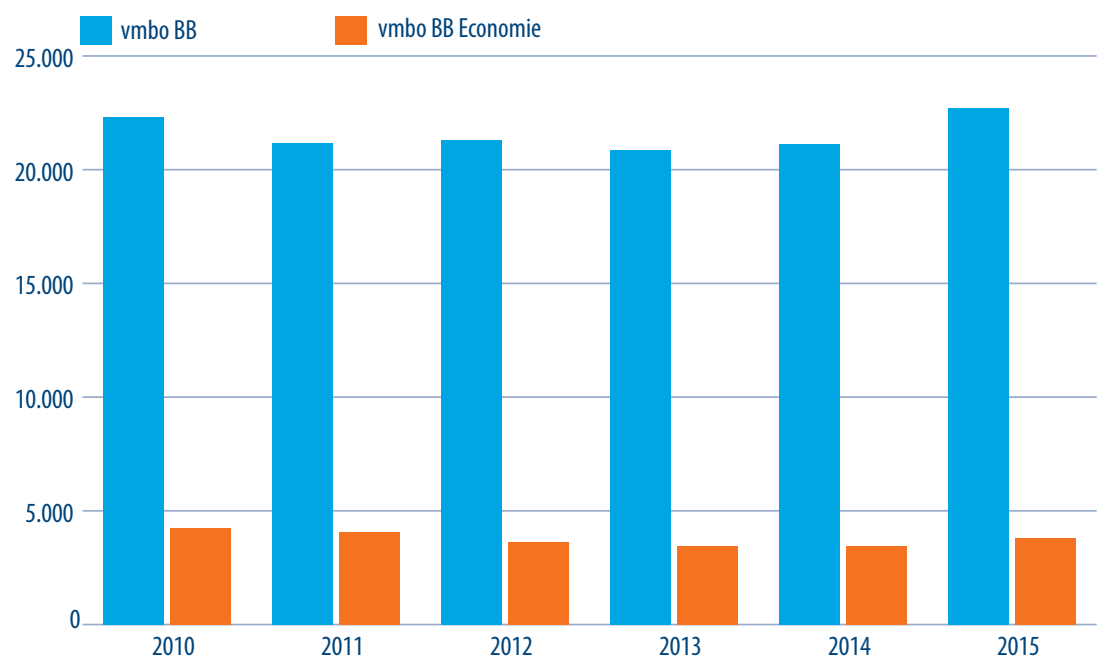

Bron: DUO (eigen berekening)

Het aandeel leerlingen in de sector Economie daalt in de onderzochte periode namelijk van 22\% (2010) naar 16-17\% (2013-2015). De daling van het aandeel in de sector Economie wordt vooral gecompenseerd door een sterke stijging van het aandeel dat een intersectoraal programma volgt. Het aandeel in deze sector stijgt namelijk van 9\% (2010) naar 22\% (2015). Naast de sector Economie zien we ook een lichte daling in de sectoren Techniek en Zorg \& Welzijn.

TABEL 3.1 Aandeel leerlingen in het derde leerjaar vmbo BB (\%)

\begin{tabular}{|l|r|r|r|r|r|r|}
\hline & 2010 & 2011 & 2012 & 2013 & 2014 & 2015 \\
\hline Economie & 22 & 20 & 19 & 17 & 16 & 17 \\
\hline Intersectoraal & 9 & 11 & 16 & 18 & 20 & 22 \\
\hline Landbouw & 14 & 15 & 15 & 15 & 15 & 15 \\
\hline Techniek & 27 & 25 & 24 & 24 & 24 & 23 \\
\hline Zorg \& Welzijn & 27 & 28 & 26 & 25 & 24 & 24 \\
\hline
\end{tabular}

Bron: DUO (eigen berekening)

Leerwegondersteuning lijkt in de vmbo BB eerder de norm dan de uitzondering. Figuur 3.2 laat zien dat het aandeel leerlingen dat leerwegondersteuning (LWOO) heeft over de cohorten, zowel voor de gehele groep in het derde leerjaar vmbo BB, als voor de groep in de sector Economie, een stijgende lijn vertoont. Het aandeel binnen de sector Economie stijgt daarbij sterker, zodat er vanaf het schooljaar 2014-2015 geen verschil meer zichtbaar is tussen de sector Economie en het aandeel binnen de vmbo BB als geheel. 
FIGUUR 3.2 Aandeel LWOO in het derde leerjaar vmbo BB (\%)

vmbo BB Economie vmbo BB

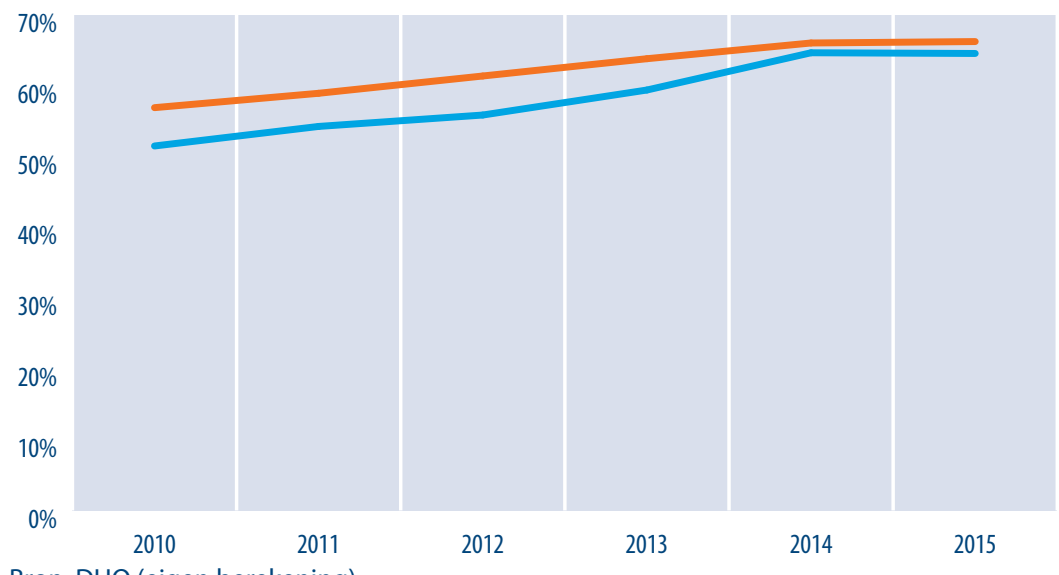

Bron: DUO (eigen berekening)

Figuur 3.3 toont dat het aandeel meisjes in het derde leerjaar van de vmbo BB als geheel, rond $45 \%$ ligt, wat ongeveer 5\%-punt hoger is dan in de sector Economie. Het aandeel blijft daarbij zowel binnen de sector Economie als binnen de vmbo BB als geheel relatief stabiel.

FIGUUR 3.3 Aandeel meisjes in het derde leerjaar vmbo BB (\%)

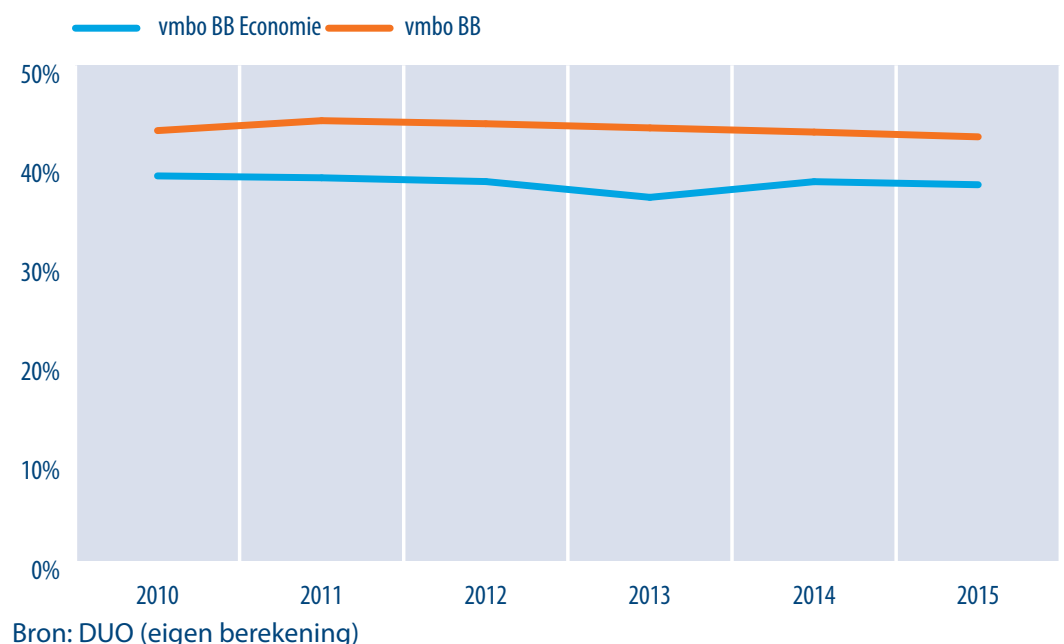

Tot slot laat Figuur 3.4 zien dat het aandeel jongeren met een niet-westerse migratieachtergrond in de sector Economie aanzienlijk hoger ligt dan het aandeel in de vmbo BB als geheel. Opvallend is dat, zeker vanaf het schooljaar 2012-2013, het aandeel in de sector Economie echter een duidelijk dalende trend kent, terwijl dit voor de gehele groep niet 
het geval is. Een reden dat de groep vmbo BB als geheel niet daalt, is dat de daling in de sector Economie gecompenseerd wordt door een vergelijkbaar hoog aandeel in de intersectorale programma's, welke tegelijk een stijgend aandeel binnen de vmbo BB kennen. Het lijkt er dan ook op dat jongeren met een niet-westerse migratieachtergrond relatief vaker in de onderzochte periode voor een intersectoraal programma, in plaats van een programma in de sector Economie gekozen hebben.

FIGUUR 3.4 Aandeel jongeren met niet-westerse migratieachtergrond in het derde jaar vmbo BB (\%)

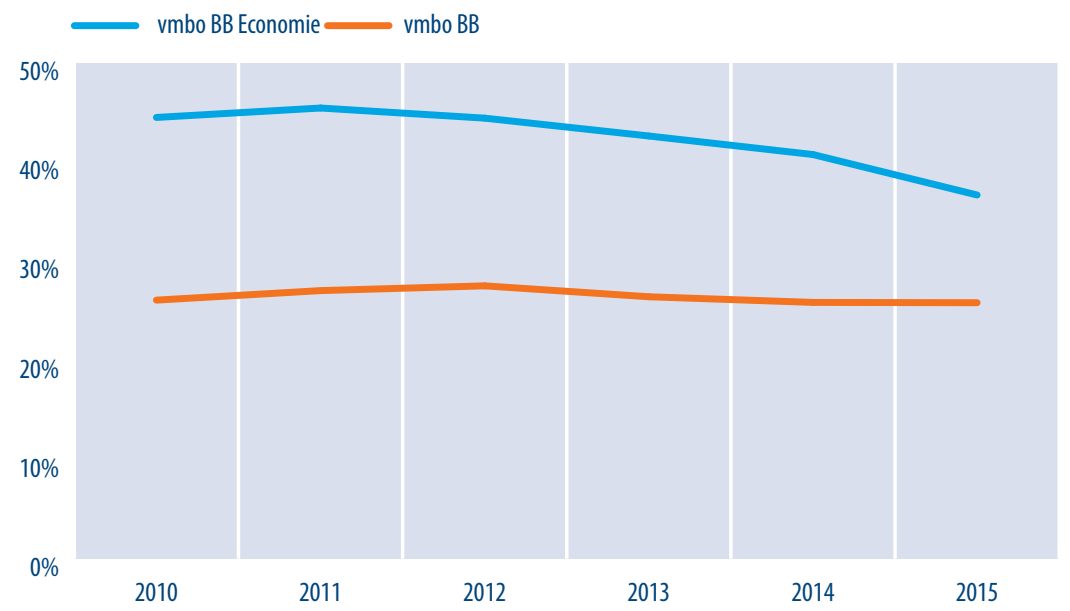

Bron: DUO (eigen berekening)

\subsection{Van het derde leerjaar vmbo BB naar het mbo}

In dit rapport staat onder andere de vraag centraal in hoeverre jongeren uit de sector Economie van het vmbo, in hun doorstroom naar het mbo, trouw blijven aan hun keuze voor een economische opleiding. Om de doorstroom naar het mbo in kaart te brengen, en om te kijken wat de verwante doorstroom vanuit een leerweg (en daarbinnen een sector) betreft, is het van belang om ons in het onderzoek te focussen op de groep die regulier binnen de geselecteerde vmbo-leerweg de opleiding volgt/afrondt (de 'main stream' groep). In Box 3.1 laten we zien wat de keuzes zijn die wij daarbij maken, en hoe wij de groep vaststellen waarvan wij uiteindelijk de doorstroom naar het mbo en het succes in het mbo vaststellen.

Van de in totaal 22.295 jongeren die volgens de beschikbare data in het schooljaar 20102011 in het derde leerjaar ingeschreven stonden, zijn twee jaar later (in het schooljaar 2012-2013) 13.606 jongeren in een mbo-niveau 2 opleiding ingeschreven. Deze groep gaan we in deze paragraaf nader analyseren. Dit betekent dat ongeveer $40 \%$ van de 
jongeren die in het schooljaar 2010-2011 in het derde leerjaar zaten, niet de 'main stream' volgden. Van de jongeren die in de sector Economie de vmbo-opleidingen volgden, was dit zelfs $45 \%$. Ondanks dat de groep jongeren die niet de 'main stream' volgde in dit rapport geen centrale rol krijgt, is het toch interessant om kort stil te staan bij deze groep. Voor deze groep zien we dat er een oververtegenwoordiging is van jongeren met een niet-westerse migratieachtergrond. Terwijl onder de autochtone jongeren $66 \%$ de'main stream' volgde, is dit onder de jongeren met een niet-westerse migratieachtergrond 'slechts' $51 \%$. We vinden echter geen verschillen tussen jongens en meisjes en tussen jongeren met of zonder leerwegondersteuning. Voordat we verder onze focussen op de 'main stream' groep, is het interessant om vast te stellen dat tot en met het schooljaar 2018-2019, van deze niet verder onderzochte groep, 56\% een mbo-diploma op minimaal niveau 2 behaald heeft (het mbo-niveau waarop een vmbo BB-opleiding in principe voorbereidt). Tegelijk heeft $30 \%$ nog geen enkel mbo-diploma behaald.

BOX 3.1 Van het vmbo BB naar het mbo: selectie

- $\quad$ In het cohort van 2010 zijn $\mathbf{2 2 . 2 9 5}$ jongeren ingeschreven in het derde leerjaar van de vmbo BB.

- $\quad$ Van de 22.295 volgden $\mathbf{2 . 0 0 8}$ jongeren een vm2 opleiding en zullen daarmee direct een mbo-niveau 2 diploma halen. Gezien deze groep afhankelijk van het gekozen cohort sterk varieert, en gezien voor deze groep de keuze voor het mbo al in het vmbo gemaakt is, stellen wij voor deze 2008 jongeren niet verder mee te nemen.

- $\quad$ Ons anker zijn daarmee de $\mathbf{2 0 . 2 8 7}$ jongeren die in het 'reguliere' vmbo BB zitten

- $\quad \mathbf{1 7 . 2 4 6}$ jongeren van de $\mathbf{2 0 . 2 8 7}$ zitten in 2011 in het vierde leerjaar van de vmbo BB. De resterende $\mathbf{3 0 4 1}$ jongeren zijn naar een andere leerweg overgestapt, zijn zitten gebleven, naar het S.O overgestapt of zijn uit het vmbo zonder diploma vertrokken (deels naar het mbo).

- $\quad$ Van de 17.246 jongeren die in 2011 nog steeds in de vmbo BB zitten, hebben 15.458 in 2011 of 2012 hun vmbo BB-diploma behaald. De rest doet er langer over, is alsnog uit het vmbo zonder diploma vertrokken, of is bijvoorbeeld alsnog van leerweg gewisseld.

- $\quad$ Uiteindelijk zijn er in $2012 \mathbf{1 4 . 4 4 2}$ jongeren die in 2011 in het derde leerjaar van de vmbo BB zaten, ingeschreven in het mbo. Van hen volgt $\mathbf{1 3 . 6 0 6}$ een opleiding op niveau 2. De rest volgt een mbo-niveau 1 opleiding (291) of, nogal verrassend, een opleiding op niveau 3 (485) of zelfs niveau 4 (60).

Nadere analyses van de andere cohorten (schooljaar 2011-2012 tot en met 2015-2016) laten zien dat het aantal jongeren afkomstig uit het derde leerjaar in de vmbo BB dat de 'main stream' volgt, licht stijgt. 
Om te beginnen, laat Tabel 3.2 zien in hoeverre jongeren met een vmbo BB-diploma die op mbo-niveau 2 instromen, voor de beroepsopleidende leerweg (mbo bol) kiezen. Onder de jongeren afkomstig uit de vmbo-sector Economie, varieert dit aandeel tussen $88 \%$ en $91 \%$. Dit is vergelijkbaar met de aandelen onder jongeren afkomstig uit de intersectorale vmbo-opleidingen en de opleiding in de sector Zorg \& Welzijn. Het aandeel dat voor een mbo bol opleiding kiest, is iets lager onder de leerlingen van de vmbosector Landbouw, en duidelijk lager onder de leerlingen van de vmbo-sector Techniek. De cijfers bevestigen eerder onderzoek dat aantoont dat de beroepsbegeleidende leerweg (mbo bbl) vooral in de mbo-sector Techniek een redelijk groot aandeel kent, terwijl, zeker in de mbo-sector Economie, de mbo bbl plaatsen schaars zijn.

TABEL 3.2 Aandeel dat in niveau 2 in bol instroomt (\%)

\begin{tabular}{|l|r|r|r|r|r|r|}
\hline & Economie & $\begin{array}{r}\text { Intersectoraal } \\
\text { programma }\end{array}$ & Landbouw & Techniek & Zorg \& Welzijn & Totaal \\
\hline 2010 & 88 & 90 & 78 & 58 & 91 & 79 \\
\hline 2011 & 90 & 93 & 82 & 67 & 93 & 84 \\
\hline 2012 & 90 & 91 & 84 & 63 & 94 & 84 \\
\hline 2013 & 91 & 91 & 83 & 64 & 93 & 84 \\
\hline 2014 & 90 & 91 & 81 & 61 & 93 & 83 \\
\hline 2014 & 90 & 91 & 83 & 59 & 94 & 83 \\
\hline
\end{tabular}

Bron: DUO (eigen berekening)

Naast een leerweg in het mbo, dienen de gediplomeerden van het vmbo ook een specifieke opleiding te kiezen. Tabel 3.3 laat zien in welk mbo-domein de jongeren instromen. Niet verrassend, laat deze tabel zien dat de doorstroom tussen het vmbo en mbo vaak tot een verwante doorstroom leidt. Met andere woorden, tot een instroom in een mboopleiding die qua vakinhoud in het verlengde van de vmbo-opleiding ligt. Zo start van het cohort 2010, 22\% van de leerlingen die we volgen uit het derde leerjaar van de vmbo-sector Economie, een opleiding in het domein Economie en Administratie ${ }^{2}$, en 21\% een opleiding in het domein Handel en Ondernemerschap. ${ }^{3}$ Bijna $45 \%$ start dus met een opleiding in een van deze twee domeinen. Daarnaast, zien we dat de domeinen Horeca en Bakkerij (18\%), Veiligheid en Sport (8\%) en Zorg \& Welzijn (8\%), relatief hoog scoren bij de studiekeuze van jongeren afkomstig uit de vmbo-sector Economie.

Een relatief hoge instroom in een van deze twee 'economische' mbo-domeinen, zien we vanuit de intersectorale vmbo-programma's (16\%) en vanuit de sectoren Zorg \& Welzijn (16\%) en Landbouw (14\%)

2 Het domein Economie en Administratie omvat in principe één beroepsopleiding, namelijk'Ondersteunende administratieve beroepen'.

3 Het domein Handel en Ondernemerschap kent in principe twee beroepsopleidingen, namelijk 'Verkoop' (zo'n 97\% van de jongeren die we in dit hoofdstuk volgen, kiezen voor deze beroepsopleiding) en 'Kleding-, confectie- en veranderatelier'. 
TABEL 3.3 Doorstroom vanuit de vmbo BB naar mbo-niveau 2 (\%); cohort 2010

\begin{tabular}{|c|c|c|c|c|c|c|}
\hline & Economie & $\begin{array}{r}\text { Intersectoraal } \\
\text { programma }\end{array}$ & Landbouw & Techniek & $\begin{array}{r}\text { Zorg \& } \\
\text { Welzijn }\end{array}$ & Alle sectoren \\
\hline Afbouw, hout en onderhoud & 1 & 1 & 1 & 8 & & 3 \\
\hline $\begin{array}{l}\text { Ambacht, laboratorium en } \\
\text { gezondheidstechniek }\end{array}$ & & & 0 & 0 & 0 & 0 \\
\hline Bouw en infra & 1 & 1 & 2 & 14 & & 4 \\
\hline Economie en administratie & 22 & 9 & 3 & 1 & 5 & 7 \\
\hline Handel en ondernemerschap & 21 & 11 & 7 & 4 & 9 & 10 \\
\hline Horeca en bakkerij & 18 & 8 & 7 & 2 & 7 & 8 \\
\hline $\begin{array}{l}\text { Informatie en } \\
\text { communicatietechnologie }\end{array}$ & 6 & 8 & 2 & 4 & 1 & 4 \\
\hline Media en vormgeving & 3 & 2 & 2 & 2 & 1 & 2 \\
\hline Mobiliteit en voertuigen & 2 & 3 & 5 & 17 & 0 & 6 \\
\hline Techniek en procesindustrie & 2 & 4 & 6 & 27 & 0 & 9 \\
\hline Toerisme en recreatie & 3 & 4 & 1 & 0 & 3 & 2 \\
\hline Transport, scheepvaart en logistiek & 3 & 4 & 3 & 7 & 1 & 4 \\
\hline Uiterlijke verzorging & 3 & 4 & 5 & 0 & 13 & 5 \\
\hline Veiligheid en sport & 8 & 24 & 7 & 7 & 5 & 8 \\
\hline Voedsel, natuur en leefomgeving & 0 & 0 & 0 & 0 & 0 & 0 \\
\hline $\begin{array}{l}\text { Voedsel, natuur en leefomgeving } \\
\text { (EZ) }\end{array}$ & 2 & 3 & 31 & 4 & 3 & 7 \\
\hline Zorg en welzijn & 8 & 16 & 19 & 2 & 52 & 21 \\
\hline Totaal & 100 & 100 & 100 & 100 & 100 & 100 \\
\hline
\end{tabular}

Bron: DUO (eigen berekening)

Analyseren we de instroom vanuit de vmbo-sector Economie in de mbo-niveau 2 opleidingen over de onderzochte periode (zie Tabel 3.4), dan zien we het volgende beeld:

- Het aandeel leerlingen dat in 2014 en 2015 in het derde jaar in de vmbo-sector Economie zaten, en die in het mbo-domein Economie en Administratie instroomt, is duidelijk lager dan in de jaren ervoor. Het aandeel daalde van 22\% naar $15 \%$.

- Het aandeel dat in het mbo-domein Handel en Ondernemerschap instroomt, blijft relatief constant rond $21 \%-22 \%$.

De combinatie van deze twee uitkomsten leidt ertoe dat één op de drie jongeren die in 2015-2016 in het derde leerjaar vmbo zat, een verwante doorstroom kent.

Als er steeds minder jongeren vanuit de economische vmbo BB-sector in een van de twee mbo-domeinen instromen, welke beroepsopleiding kiezen ze dan? Vergelijken we de jongeren uit het schooljaar 2010-2011 met de jongeren uit het schooljaar 2015-2016, 
dan zien we dat vooral het aandeel dat voor een mbo-opleiding in het domein Zorg \& Welzijn kiest, een sterke stijging kent. Terwijl van het eerste cohort nog $8 \%$ van de leerlingen voor een Zorg \& Welzijn opleiding koos, is dit in het cohort 2015-2016 met 17\% twee keer zo hoog.

TABEL 3.4 Instroom in economische mbo-domeinen vanuit de vmbo-sector Economie over de jaren (\%)

\begin{tabular}{|l|r|r|r|r|r|r|r|}
\hline Economie en Administratie & 2010 & 2011 & 2012 & 2013 & 2014 & 2015 \\
\hline Handel en Ondernemerschap & 22 & 22 & 21 & 19 & 17 & 15 \\
\hline Ander domein & 21 & 22 & 21 & 23 & 21 & 21 \\
\hline Totaal & 57 & 56 & 58 & 58 & 62 & 64 \\
\hline
\end{tabular}

Bron: DUO (eigen berekening)

De data laten ons ook toe na te gaan of de verwante doorstroom vanuit de vmbo-sector Economie verschilt tussen jongens en meisjes en tussen jongeren met verschillende etnische achtergrond. Van de jongeren met een niet-westerse migratieachtergrond die in het schooljaar 2010-2011 in de vmbo BB-sector Economie zaten, stroomde 37\% door naar het domein Economie en Administratie en 23\% naar het domein Handel en Ondernemerschap. Dit is aanzienlijk hoger dan onder de autochtone jongeren waar de percentages respectievelijk $11 \%$ en $20 \%$ zijn. Voor beide groepen daalt het percentage over de jaren heen, maar ook voor het cohort 2015 (instroom in mbo in 2017) zien we nog steeds duidelijke verschillen. Onder de jongeren met een niet-westerse migratieachtergrond zijn de aandelen in het cohort 2015 26\% voor beide mbo-domeinen terwijl voor de autochtone jongeren de aandelen 7\% (Economie en Administratie) en 18\% (Handel en Ondernemerschap) zijn. Een ander verschil zien we als we de instroomcijfers in de mbo-niveau 2 domeinen analyseren voor jongens en meisjes. Meisjes kiezen vaker voor het domein Economie en Administratie (van het cohort 2015 koos 18\% van de meisjes en $13 \%$ van de jongens voor dit domein) en vergelijkbaar voor het domein Handel en Ondernemerschap. Naast deze twee domeinen kozen meisjes relatief vaker voor de domeinen Zorg \& Welzijn (28\%) en Horeca en Bakkerij (16\%) en jongens voor de domeinen Horeca en Bakkerij (15\%), Informatie en Communicatietechnologie (11\%), Zorg en Welzijn (10\%) en Veiligheid en Sport (7\%).

Tot zover hebben we gekeken naar de instroom in de mbo-niveau 2 opleiding. De beschikbare data geven echter ook de mogelijkheid om te kijken in hoeverre jongeren ook daadwerkelijk een mbo-niveau 2 (of hoger) diploma behalen.

Tabel 3.5 laat voor de groep die in het schooljaar 2010-2011 in het derde leerjaar vmbo zat en die twee jaar later in een mbo-niveau 2 opleiding instroomde, zien in hoeverre ze tot en met het schooljaar 2017-2018 een mbo-diploma hebben behaald. Van de totale groep, 
heeft in deze periode $17 \%$ nog geen enkel mbo-diploma behaald ${ }^{4}$, heeft $44 \%$ maximaal een mbo-niveau 2 diploma behaald, heeft $29 \%$ al een mbo-niveau 3 diploma en heeft $10 \%$ zelfs al een mbo-niveau 4 diploma. ${ }^{5}$ De verschillen tussen jongeren afkomstig uit de onderscheiden vmbo-sectoren zijn daarbij relatief klein. Zo varieert het aandeel dat nog geen mbo-diploma heeft behaald, tussen de 14\% (Zorg \& Welzijn) en 19\% (Techniek), en varieert het aandeel dat al een niveau 3 of 4 diploma heeft behaald, tussen $45 \%$ (Zorg \& Welzijn) en 34\% (Techniek). De jongeren afkomstig uit de vmbo-sector Economie zijn daarbij sterk vergelijkbaar met het gemiddelde beeld.

TABEL 3.5 Hoogst behaald mbo-diploma tot en met schooljaar 2017-2018 indien instroom in niveau 2 (\%)

\begin{tabular}{|l|r|r|r|r|r|}
\hline & (Nog) geen mbo-diploma & Niveau 1 & Niveau 2 & Niveau 3 & Niveau 4 \\
\hline Economie & 18 & 0 & 42 & 25 & 14 \\
\hline Intersectoraal programma & 16 & 0 & 46 & 25 & 13 \\
\hline Landbouw & 15 & 1 & 47 & 31 & 7 \\
\hline Techniek & 19 & 0 & 48 & 28 & 6 \\
\hline Zorg \&Welzijn & 14 & 0 & 41 & 35 & 10 \\
\hline Alle sectoren & 17 & 0 & 44 & 29 & 10 \\
\hline
\end{tabular}

Bron: DUO (eigen berekening)

Nadere analyses laten overigens zien dat jongeren die in het vmbo LWOO hadden, het iets beter doen. Van hen heeft 17\% nog geen diploma, 41\% een niveau 2-diploma, 28\% een niveau 3-diploma en $14 \%$ een niveau 4-diploma. Voor de jongeren zonder LWOO zijn de cijfers respectievelijk 20\%, 43\%, 22\% en $14 \%$.

Figuur 3.5 laat zien in hoeverre er verschillen zijn tussen leerlingen met een niet-westerse migratieachtergrond en autochtone leerlingen. We onderscheiden daarbij ook onmiddellijk de leerlingen die in het vmbo in de sector Economie zaten. Een tweetal resultaten vallen op:

1. Het aandeel leerlingen met een niet-westerse migratieachtergrond dat nog geen diploma heeft behaald is ongeveer $4 \%$-punt hoger dan het aandeel autochtone leerlingen zonder diploma.

2. Het aandeel leerlingen met een niet-westerse migratieachtergrond dat een mboniveau 4 diploma heeft behaald is hoger dan het aandeel autochtone leerlingen.

$4 \quad$ Nadere analyses van de leerlingen die nog geen mbo-diploma hebben behaald, laten zien dat $11 \%$ van deze leerlingen in het schooljaar 2018-2019 een geldige inschrijving hebben (waarvan 98\% in het mbo). $89 \%$ heeft in dit schooljaar geen (geldige) inschrijving in het Nederlandse onderwijssysteem zover geregistreerd bij DUO. Hierbij doen zich geen duidelijke verschillen voor tussen jongeren afkomstig uit de onderscheiden vmbo BB-sectoren op basis van de inschrijving in het derde leerjaar in het schooljaar 2010-2011.De data laten niet toe om verder vast te stellen of de jongeren die niet meer in het onderwijs ingeschreven staan nog in Nederland woonachtig zijn of niet.

5 In hoeverre gediplomeerden van het mbo-niveau 4 doorstromen naar een opleiding in het hbo staat in Paragraaf 5 centraal. 
Onder de jongeren uit de vmbo-sector Economie is dit $17 \%$ voor de leerlingen met een niet-westerse migratieachtergrond versus $10 \%$ voor de autochtone leerlingen. ${ }^{6}$

FIGUUR 3.5 Hoogst behaald mbo-diploma naar etnische achtergrond (cohort 2010) (\%)

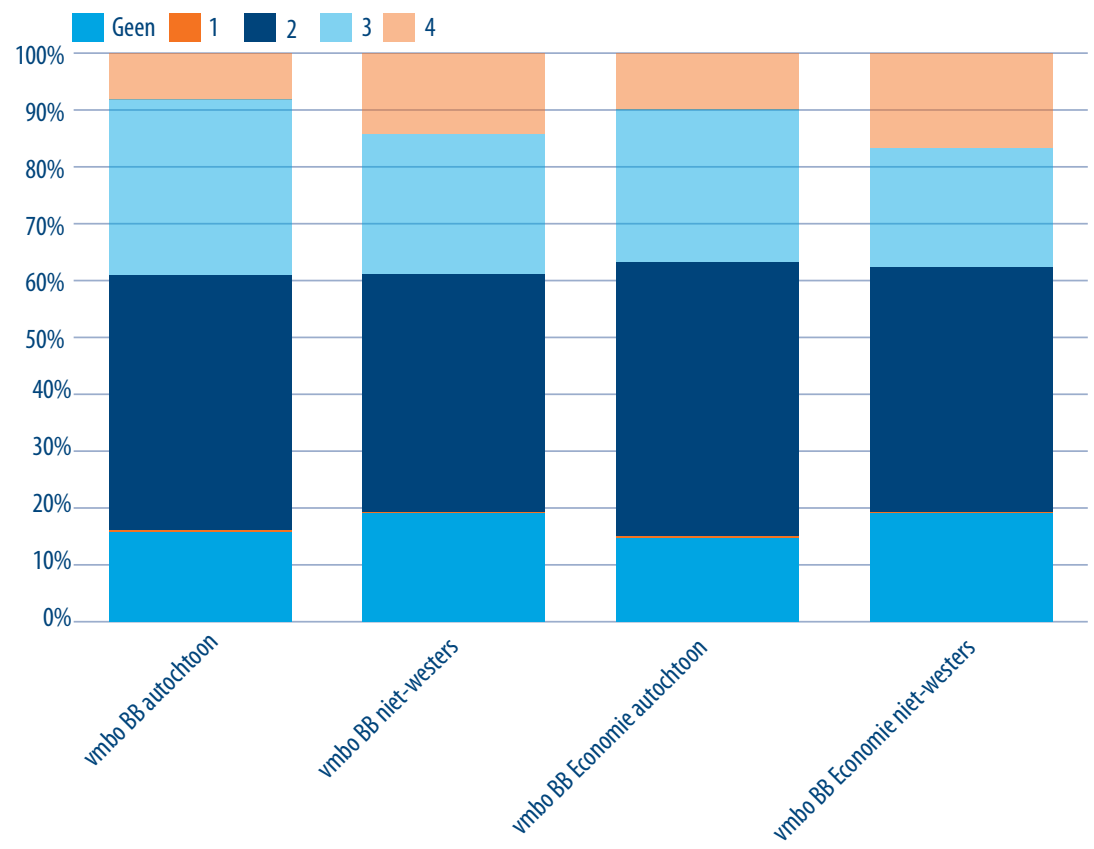

Bron: DUO (eigen berekening)

In de context van het voorliggende onderzoek, is het interessant om verder stil te staan bij de vraag of het mbo-domein waarin men het diploma behaalt ook het mbo-domein is waarin men in eerste instantie ingestroomd is. Met andere woorden, leidt verwante doorstroom vanuit het vmbo naar het mbo ook naar een verwant diploma? Tabel 3.6 laat daarom voor het cohort van 2010 zien in welk domein de vmbo Economie gediplomeerden het eerste mbo-niveau 2 diploma behalen, en zet deze af tegen het domein waarin ze ingestroomd zijn.

- $84 \%$ van degenen die in het mbo-domein Economie en Administratie instroomt en tot en met het schooljaar 2017-2018 een diploma op niveau 2 behaalde, heeft dit diploma ook in deze sector behaald. Voor Handel en Ondernemerschap is dit aandeel zelfs $89 \%$.

6 Eerder hebben we al vastgesteld dat het aandeel onder de jongeren met een niet-westerse migratieachtergrond dat de 'main stream' door het vmbo volgde, kleiner is dan onder de autochtone jongeren. Samen met de observatie dat de 'extremen' relatief groter lijken te zijn onder jongeren met een niet-westerse migratieachtergrond, met betrekking tot het behalen van een mbo-diploma, kan het erop duiden dat de groep jongeren met een niet-westerse migratieachtergrond die een vmbo BB-opleiding volgen, een heterogenere groep is dan de groep autochtone jongeren. 
- Voor jongeren die in een van deze domeinen instromen, maar uiteindelijk niet in hetzelfde domein het mbo-niveau 2 diploma behalen, zien we dat dit vaak samen gaat met een wissel naar een niet-economische domein.

TABEL 3.6 Mbo-domein: instroom versus mbo-domein: diploma niveau 2, cohort 2010 (\%)

\begin{tabular}{|c|c|c|c|c|}
\hline & & \multicolumn{3}{|c|}{ Mbo-domein: instroom } \\
\hline & & $\begin{array}{l}\text { Economie en } \\
\text { Administratie }\end{array}$ & $\begin{array}{r}\text { Handel en } \\
\text { Ondernemerschap }\end{array}$ & Ander domein \\
\hline \multirow{4}{*}{$\begin{array}{l}\text { Mbo-domein: } \\
\text { Diploma } \\
\text { niveau } 2\end{array}$} & Economie en Administratie & 84 & 2 & 3 \\
\hline & Handel en Ondernemerschap & 5 & 89 & 4 \\
\hline & Ander domein & 11 & 9 & 92 \\
\hline & Totaal & 100 & 100 & 100 \\
\hline
\end{tabular}

Bron: DUO (eigen berekening)

\subsection{Mbo-niveau 2 diploma: en nu?}

De basisberoepsgerichte leerweg van het vmbo bereidt in principe voor op het behalen van een mbo-niveau 2 diploma. Terwijl formeel een mbo-niveau 2 diploma een startkwalificatie biedt voor de arbeidsmarkt, kiest een groot deel van de mbo-niveau 2 gediplomeerden voor een vervolgopleiding. Zonder twijfel hangt dit gedeeltelijk samen met de vaak relatief magere arbeidsmarktperspectieven van mbo-niveau 2 opleidingen (zie o.a. ROA, 2017). In deze paragraaf analyseren we dan ook in hoeverre jongeren met een mbo-niveau 2 diploma succesvol een vervolgstudie afronden en daarmee een hoger mbo-diploma, met in de regel betere arbeidsmarktperspectieven behalen.

De navolgende analyses zijn daarbij wederom gebaseerd op een databestand van DUO. Echter, dit keer analyseren we de gegevens van mbo-niveau 2 gediplomeerden van het schooljaar 2012-2013. Ook hier is het belangrijk dat we een zo homogeen mogelijk groep analyseren, dit in verband met een tweetal aspecten:

- Ten eerste, de volgende analyses dienen als vervolg van de eerdere analyses beschouwd te worden. Dit wil zeggen dat we ons ook in deze paragraaf focussen op jongeren die voorafgaand aan de mbo-niveau 2-opleiding een vmbo BB-diploma behaald hebben.

- Ten tweede, in de voorafgaande analyses hebben we de nadruk gelegd op de jongeren die de 'main stream' volgden. We doen dit in de volgende analyses wederom zo goed mogelijk door alleen gediplomeerden van een mbo-niveau 2 opleiding mee te nemen.

In het schooljaar 2012-2013 zijn in totaal 55.686 mbo-niveau 2 diploma's uitgereikt. Bijna 10.000 daarvan zijn aan examendeelnemers uitgereikt. Dit uitzonderlijk hoog aantal is grotendeels gerelateerd aan het feit dat in deze periode o.a. voor gastouders de diplo- 
maverplichting is aangescherpt. Van de resterende 45.000 mbo-niveau 2 diploma's zijn iets minder dan 17.000 behaald door leerlingen die op het moment van behalen van het diploma, jonger dan 27 jaar waren en voorafgaand aan de mbo-niveau 2 opleiding een vmbo BB-diploma behaald hebben. Deze 16.685 jongeren zullen in de voorliggende paragraaf dan ook de basis vormen voor de analyses.

Tabel 3.7 laat zien dat $48 \%$ van de gediplomeerden van het mbo-domein Handel en Ondernemerschap en zelfs $56 \%$ van de gediplomeerden van het domein Economie en Administratie tot en met het schooljaar 2017-2018 een verder diploma in het mbo behaald heeft. Een klein deel daarvan heeft voor een tweede diploma op niveau 2 gekozen $(2-3 \%)$ terwijl het gros een diploma op niveau 3 of 4 behaalde. Onder de gediplomeerden van het mbo-domein Economie en Administratie heeft zelfs al $29 \%$ een diploma op niveau 4 behaald terwijl dit onder de gediplomeerden van het domein Handel en Ondernemerschap zo'n $16 \%$ is. Vergelijken we deze uitkomsten met de resultaten van de gediplomeerden van andere domeinen, dan zien we dat de gediplomeerden van het mbo-domein Economie en Administratie samen met de gediplomeerden van het domein Ambacht, Laboratorium en Gezondheidstechniek aan de top staan, wat het behalen van een mbo-niveau 4 diploma betreft. De gediplomeerden van het domein Handel en Ondernemerschap doen het in dit opzicht gemiddeld.

TABEL 3.7 Mbo-diploma na behalen van mbo-niveau 2 diploma in 2012-2013 (\%)

\begin{tabular}{|l|r|r|r|r|}
\hline & Geen & niveau 2 & niveau 3 & niveau 4 \\
\hline Afbouw, hout en onderhoud & 53 & 4 & 34 & 9 \\
\hline Ambacht, laboratorium en gezondheidstechniek & 40 & & 30 & 30 \\
\hline Bouw en infra & 51 & 6 & 38 & 4 \\
\hline Economie en administratie & 44 & 2 & 25 & 29 \\
\hline Handel en ondernemerschap & 52 & 3 & 29 & 16 \\
\hline Horeca en bakkerij & 49 & 5 & 36 & 10 \\
\hline Informatie en communicatietechnologie & 39 & 2 & 34 & 26 \\
\hline Media en vormgeving & 36 & 3 & 31 & 29 \\
\hline Mobiliteit en voertuigen & 48 & 4 & 39 & 9 \\
\hline Techniek en procesindustrie & 48 & 4 & 38 & 10 \\
\hline Toerisme en recreatie & 47 & 3 & 30 & 20 \\
\hline Transport, scheepvaart en logistiek & 70 & 6 & 19 & 4 \\
\hline Uiterlijke verzorging & 30 & 1 & 63 & 6 \\
\hline Veiligheid en sport & 60 & 6 & 23 & 12 \\
\hline Voedsel, natuur en leefomgeving & 61 & 5 & 27 & 72 \\
\hline Voedsel, natuur en leefomgeving (EZ) & 56 & 4 & 34 & 14 \\
\hline Zorg en welzijn & 42 & & 5 \\
\hline Bron: DUO (eigen berekening) & & & 5 \\
\hline
\end{tabular}

Bron: DUO (eigen berekening) 
Vergelijkbaar met de doorstroom tussen het vmbo en het mbo laten nadere analyses zien dat de doorstroom naar een hoger mbo-niveau in de meeste gevallen binnen verwante opleidingen plaatsvindt. Zo behaalt $70 \%$ van de niveau 2 gediplomeerden van het domein Economie en Administratie hun niveau 3 of 4 diploma wederom in dit domein, wisselt $6 \%$ naar het domein Handel en Ondernemerschap en behaalt $24 \%$ zijn vervolgdiploma buiten de twee genoemde domeinen. Jongeren die buiten de twee onderscheiden domeinen het diploma behalen, wisselen vooral naar het domein Zorg \& Welzijn (12\%) en Toerisme en Recreatie (6\%). Onder de gediplomeerden van het domein Handel en Ondernemerschap zien we vergelijkbare cijfers. Zo behaalt $68 \%$ het niveau 3 of 4 diploma wederom in hetzelfde domein en wisselt $8 \%$ naar het domein Economie en Administratie. Ook hier blijven daarmee drie op de vier gediplomeerden trouw aan een economische opleiding. Alternatieven voor deze twee onderscheiden domeinen zijn vooral opleidingen in het domein Zorg \& Welzijn (12\% wisselt naar dit domein) en in mindere mate opleidingen in de domeinen Uiterlijke verzorging (3\%) en Toerisme en Recreatie (2\%).

Eerder hebben we al vastgesteld dat van de jongeren afkomstig uit het derde leerjaar van de vmbo BB, de jongeren met een niet-westerse migratieachtergrond vaker binnen deze periode een mbo-niveau 4 diploma behaalden. Tegelijk waren zij ook de groep die vaker geen mbo-diploma had behaald. Op basis van de data met betrekking tot de mbo-niveau 2 gediplomeerden komt een vergelijkbaar beeld naar voor (zie Tabel 3.8). Onder de groep mbo-niveau 2 gediplomeerden (schooljaar 2012-2013) met een nietwesterse migratieachtergrond in het domein Economie en Administratie, heeft tot en met het schooljaar 2017-2018 31\% een mbo-niveau 4 diploma behaald. Dit is 4\%-punt hoger dan onder de autochtone gediplomeerden. Binnen de groep die een diploma in het domein Handel en Ondernemerschap behaalde zijn de verschillen zelfs iets groter: $20 \%$ van de jongeren met een niet-westerse migratieachtergrond heeft al een mbo-niveau 4 diploma behaald tegenover $14 \%$ onder de autochtone gediplomeerden.

TABEL 3.8 Vervolgdiploma naar etnische achtergrond na behalen van mbo-niveau 2 diploma in 2012-2013 (\%)

\begin{tabular}{|l|r|r|r|r|}
\hline Economie en Administratie & Geen & 2 & 3 & 4 \\
\hline Westerse & & & & \\
\hline Niet-westerse & 46 & 4 & 30 & 21 \\
\hline Autochtoon & 43 & 1 & 25 & 31 \\
\hline Handel en Ondernemerschap & 46 & 4 & 23 & 27 \\
\hline Westerse & & & & \\
\hline Niet-westerse & 55 & 5 & 26 & 14 \\
\hline Autochtoon & 51 & 1 & 28 & 20 \\
\hline
\end{tabular}

Bron: DUO (eigen berekening) 



\section{VMBO KADERBEROEPSGERICHTE LEERWEG}

In dit hoofdstuk gaan we in op de jongeren die in het vmbo de kaderberoepsgerichte leerweg (vmbo KB) volgen. Dit hoofdstuk kent een gelijkaardige opbouw als Hoofdstuk 3. We staan eerst stil bij de jongeren die in het derde leerjaar van de vmbo KB zitten (Paragraaf 4.1) en laten de ontwikkeling zien van het aantal jongeren alsook de verdeling over de verschillende vmbo-sectoren. Ook kijken we naar een aantal kenmerken van deze jongeren (geslacht, etnische achtergrond en leerwegondersteuning). In Paragraaf 4.2 volgen we de jongeren in hun doorstroom naar het mbo, en stellen we de vraag hoe succesvol zij in hun vervolgopleidingen zijn. De focus ligt daarbij op mbo-niveau 3 en 4, aangezien de kaderberoepsgerichte leerweg van het vmbo ter voorbereiding voor deze hogere mbo-niveaus dient. Tot slot, stellen we in Paragraaf 4.3 de vraag hoe de gediplomeerden van de vmbo KB terugkijken op hun gevolgde opleiding. In tegenstelling tot Hoofdstuk 3 , laten we de gediplomeerden van mbo-opleidingen waar de vmbo KB op voorbereidt, en hun vervolgstappen in het onderwijs, even buiten beschouwing. In Hoofdstuk 6 komen we terug op deze groep nadat we in Hoofdstuk 5 de leerlingen van de gemengde en theoretische leerweg in hun weg richting het mbo geanalyseerd hebben. In Hoofdstuk 6 analyseren we dan de vervolgwegen van de gediplomeerden van de mbo-niveau 4 opleidingen, en kijken we naar mogelijke verschillen naar vooropleiding (vmbo KB of GL/TL).

\subsection{Het derde leerjaar}

Figuur 4.1 laat het aantal leerlingen in het derde leerjaar van de vmbo KB zien. Naast het totale aantal leerlingen, laten we ook het aantal leerlingen in het derde leerjaar zien dat ingeschreven staat in de sector Economie. Terwijl het aantal leerlingen in het vmbo KB over de onderzochte periode stijgt van net onder 27.000 naar net boven 30.000, laat Figuur 4.1 een dalende trend voor het aantal leerlingen in de sector Economie zien. Terwijl het aantal in het schooljaar 2010-2011 nog zo'n 6.700 was, daalt het in het schooljaar 2013-2014 tot 5.800. Hierna stijgt het weliswaar licht, maar ligt het aantal in het schooljaar 2015-2016 nog steeds bijna 10\% onder het niveau van 2010-2011. 
FIGUUR 4.1 Aantal leerlingen in het derde leerjaar vmbo KB

$35.000 \_$vmbo KB vmbo KB Economie

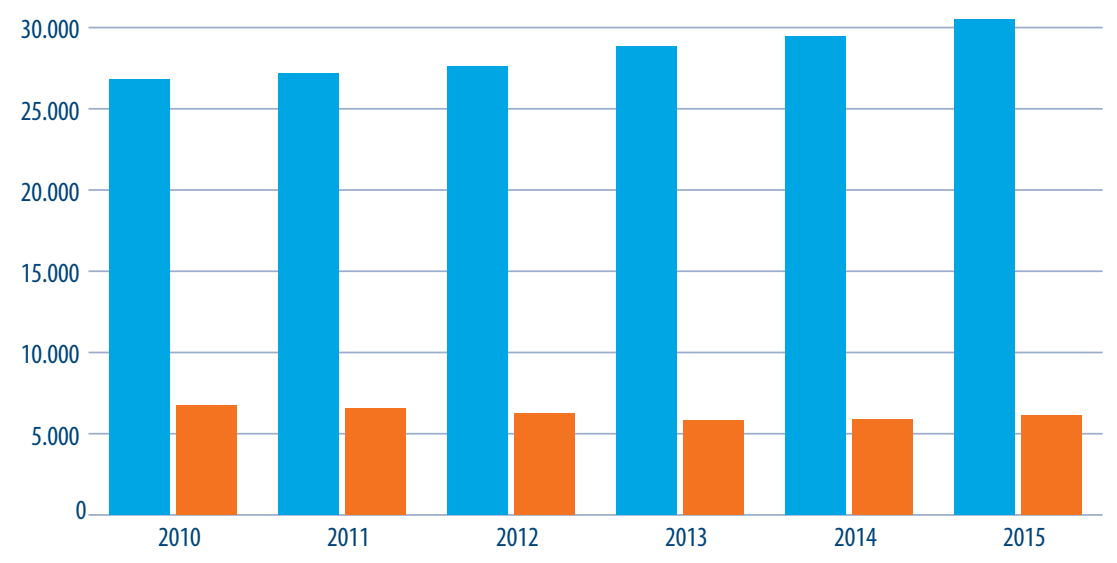

Bron: DUO (eigen berekening)

Op basis van de cijfers in Figuur 4.1 werd al duidelijk dat het aandeel leerlingen dat in de vmbo KB een opleiding in de sector Economie volgde, over de onderzochte periode daalde. Dit wordt bevestigd in Tabel 4.1. Terwijl in het schooljaar 2010-2011 nog één op de vier leerlingen in het derde leerjaar ingeschreven stond in de sector Economie, is dit vanaf het schooljaar 2013-2014 nog één op de vijf. Vergelijkbaar met de resultaten voor de vmbo BB zien we ook hier vooral een sterke stijging in de intersectorale programma's (van 12\% in het schooljaar 2010-2011 naar 24\% in het schooljaar 2015-2016).

TABEL 4.1 Aandeel leerlingen in het derde leerjaar vmbo KB (\%)

\begin{tabular}{|l|r|r|r|r|r|r|}
\hline & 2010 & 2011 & 2012 & 2013 & 2014 & 2015 \\
\hline Economie & 25 & 24 & 23 & 20 & 20 & 20 \\
\hline Intersectoraal programma & 12 & 16 & 19 & 22 & 23 & 24 \\
\hline Landbouw & 11 & 10 & 10 & 10 & 11 & 11 \\
\hline Techniek & 24 & 23 & 22 & 22 & 22 & 22 \\
\hline Zorg \& Welzijn & 28 & 27 & 27 & 26 & 23 & 23 \\
\hline
\end{tabular}

Bron: DUO (eigen berekening)

Terwijl het aandeel leerlingen in de vmbo BB dat leerwegondersteuning had in de onderzochte periode een stijgende trend vertoont, laat Figuur 4.2 zien dat in de vmbo KB het aandeel relatief constant blijft. Met een aandeel tussen $26 \%$ en $28 \%$, is dit dan ook ongeveer de helft van het aandeel in de vmbo BB. Daarbij is geen verschil zichtbaar tussen de gehele populatie van de vmbo KB en de sector Economie. 
FIGUUR 4.2 Aandeel LWOO in het derde leerjaar vmbo KB (\%)

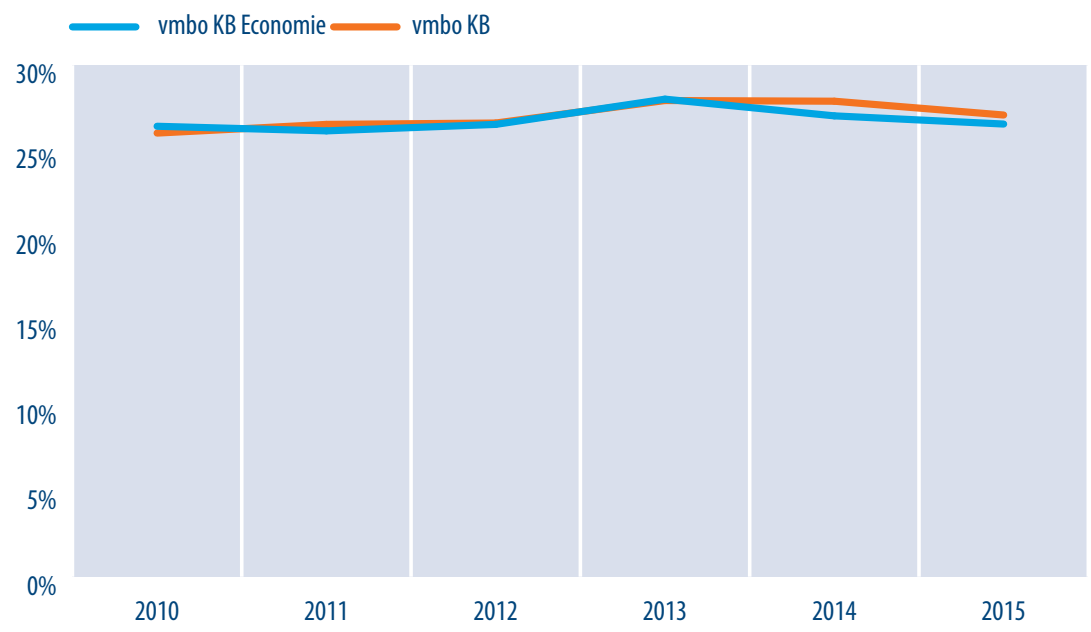

Bron: DUO (eigen berekening)

Het aandeel meisjes in het derde leerjaar van de vmbo KB ligt in de onderzochte periode relatief constant rond $47 \%$. In de sector Economie, ligt dit aandeel iets lager, namelijk rond $42 \%$ (Figuur 4.3). Het verschil in de jongens-meisjes verhouding tussen de leerweg in zijn geheel en de sector Economie, is daarbij sterk vergelijkbaar met de situatie in de vmbo BB.

FIGUUR 4.3 Aandeel meisjes in het derde leerjaar vmbo KB (\%)

vmbo KB Economie $\longrightarrow$ vmbo KB

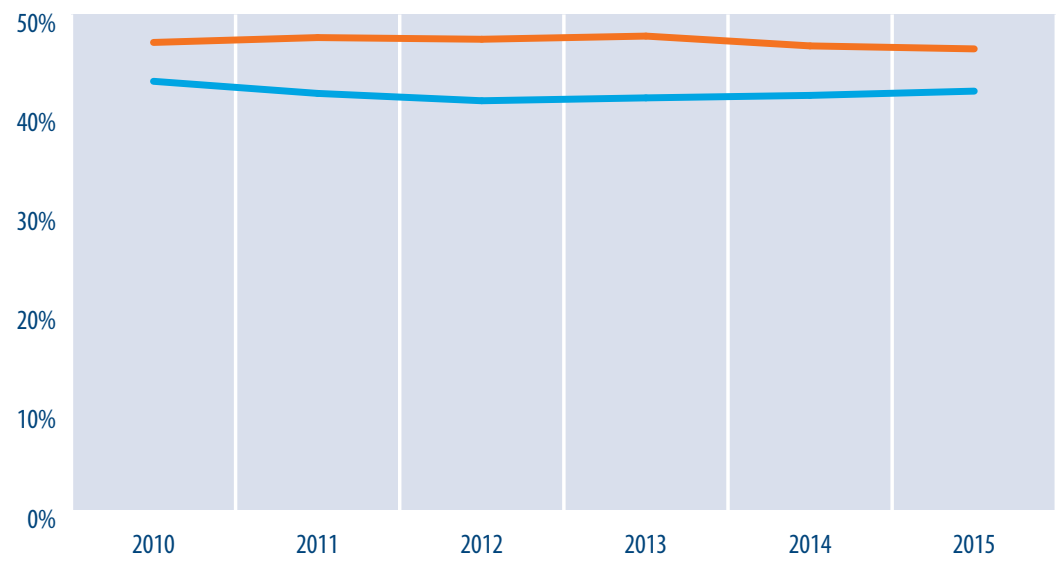

Bron: DUO (eigen berekening) 
Tot slot laat Figuur 4.4 zien dat het aandeel leerlingen met een niet-westerse migratieachtergrond in de vmbo KB in de onderzochte periode relatief stabiel rond $20 \%$ ligt. Vergelijkbaar met onze bevinding in de vmbo BB, zien we echter dat het aandeel met een niet-westerse migratieachtergrond in de sector Economie een dalende lijn kent. Ook hier laten nadere analyses zien dat de daling in de sector Economie voor de vmbo KB in zijn geheel, gecompenseerd wordt door de sterke stijging van het aandeel leerlingen in de intersectorale sector, die vergelijkbaar met de sector Economie, een relatief sterke aantrekkingskracht kent voor jongeren met een niet-westerse migratieachtergrond. Ondanks de dalende trend in het aandeel met een niet-westerse migratieachtergrond in de sector Economie, benadrukken we dat dit aandeel over de hele periode boven het aandeel voor de gehele vmbo KB ligt.

FIGUUR 4.4 Aandeel jongeren met niet-westerse migratieachtergrond in het derde leerjaar vmbo $\mathrm{KB}(\%)$

vmbo KBEconomie vmbo KB

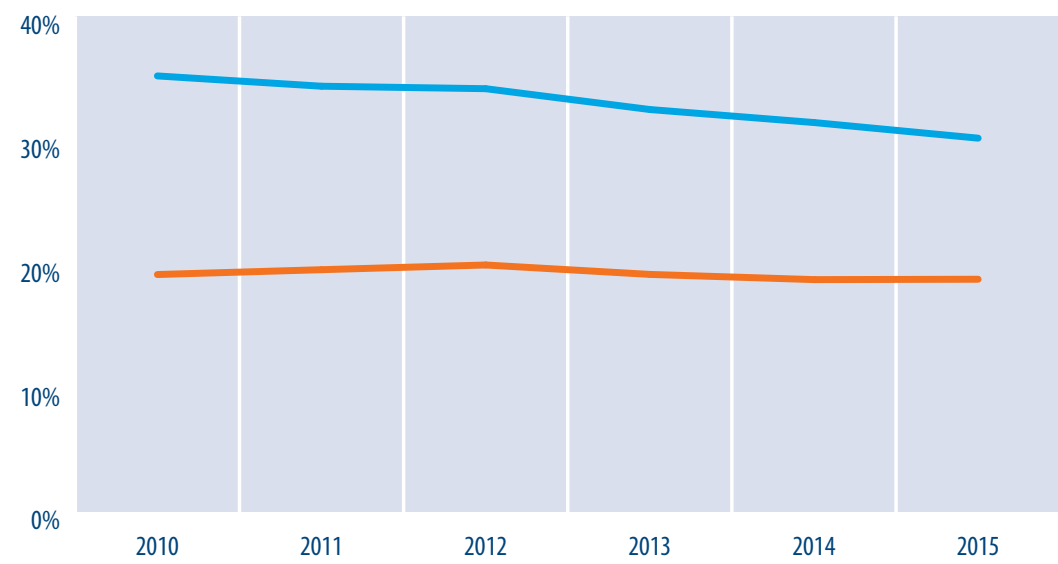

Bron: DUO (eigen berekening)

\subsection{Van het derde leerjaar vmbo KB naar het mbo}

In het voorliggende rapport staat de vraag centraal in hoeverre jongeren vanuit de vmbo-sector Economie in hun doorstroom naar het mbo, trouw blijven aan hun keuze voor een economische opleiding. Om de doorstroom naar het mbo in kaart te brengen, en om te kijken naar de verwante doorstroom vanuit een leerweg (en daarbinnen een sector), focussen we op de groep die regulier binnen de geselecteerde vmbo-leerweg de opleiding volgt/afrondt (de 'main stream' groep). In Box 4.1 laten we zien wat de keuzes zijn die wij daarbij maken, en hoe wij de groep bekomen waarvan we uiteindelijk de doorstroom naar het mbo en het succes in het mbo vaststellen. We doen dit aan de hand van het cohort van 2010. De uiteindelijke groep uit het cohort van 2010 (het derde 
leerjaar vmbo KB) waarvoor de doorstroom naar een bepaald mbo-domein in 2012 vastgesteld kan worden, is daarmee 20.831 jongeren (78\% van de oorspronkelijke groep). Voor deze groep zal in deze paragraaf de doorstroom naar een bepaald mbo-domein vastgesteld worden, alsook het succes in deze opleiding. Met andere woorden, $22 \%$ van de jongeren die in het schooljaar 2010-2011 in het derde leerjaar zaten, bewandelen niet de 'main stream' weg. Van de jongeren in de vmbo-opleiding in de sector Economie, is het aandeel dat de 'mainstream' weg bewandelde vergelijkbaar. Ondanks dat de groep jongeren die niet tot de 'main stream' behoort in dit rapport geen centrale rol krijgt, is het interessant om toch kort stil te staan bij deze groep. Deze laat een oververtegenwoordiging van jongeren met een niet-westerse migratieachtergrond zien. Terwijl onder de autochtone jongeren $80 \%$ de 'main stream' bewandelt, is dit onder de jongeren met een niet-westerse migratieachtergrond 'slechts' $69 \%$. We vinden geen verschillen tussen jongens en meisjes en een licht verschil tussen jongeren met en zonder LWOO. Van de groep jongeren die niet de 'main stream' weg bewandelde heeft tot en met het schooljaar 2017-2018 29\% een mbo-niveau 2 diploma behaald en 35\% minimaal een mbo-niveau 3 diploma. Hiertegenover staat dat bijna $30 \%$ nog geen mbo-diploma heeft behaald.

BOX 4.1 Van vmbo KB naar mbo: selectie

In het cohort van 2010 zijn $\mathbf{2 6 . 7 8 5}$ jongeren ingeschreven in het derde leerjaar van de vmbo KB.

- $\mathbf{2 3 . 3 5 9}$ van de $\mathbf{2 6 . 7 8 5}$ jongeren zitten in 2011 in het vierde leerjaar van de vmbo KB. De overige $\mathbf{3 . 4 2 6}$ jongeren zijn naar een andere leerweg overgestapt, zijn zitten gebleven, naar het S.O. overgestapt of zijn uit het vmbo zonder diploma vertrokken (deels naar het mbo).

- Van de 23.359 jongeren die in 2011 nog steeds in de vmbo KB zitten, hebben 22.048 in 2011 of 2012 hun vmbo KB-diploma behaald. De rest doet er langer over, is alsnog uit het vmbo zonder diploma vertrokken of is bijvoorbeeld van leerweg gewisseld.

- Uiteindelijk zijn er in $2012 \mathbf{2 0 . 8 3 1}$ jongeren die in 2011 in het derde leerjaar van de vmbo KB zaten, ingeschreven in het mbo. Van hen volgen er $\mathbf{9 . 1 8 1}$ een mbo-niveau 3 opleiding en 7.560 een mbo-niveau 4 opleiding. De rest zit momenteel in een mbo-niveau 2 opleiding (4.054) of zelfs in een mbo-niveau 1 opleiding (36).

Nadere analyses van de andere cohorten (schooljaar 2011-2012 tot en met 2015-2016) laten zien dat het aantal jongeren afkomstig uit het derde leerjaar vmbo KB dat de 'main stream' bewandelt, licht stijgt.

Een diploma van de kaderberoepsgerichte leerweg biedt toegang tot alle mbo-opleidingen tot en met niveau 4. Dit betekent dat in tegenstelling tot de doorstroom vanuit de basisberoepsgerichte leerweg, we voor de doorstroom vanuit de kaderberoepsgerichte leerweg dienen rekening te houden met het mbo-opleidingsniveau waarin de leerlingen instromen. In tegenstelling tot de instroom in de beroepsopleidende leerweg (mbo bol), waar instroom in de regel in het beoogde eindniveau plaatsvindt, vindt de 
instroom in de beroepsbegeleidende leerweg (mbo bbl) in de regel op mbo-niveau 2 plaats, waarna via verschillende stappen een hoger diploma bereikt wordt. Hierdoor dienen we onmiddellijk ook rekening te houden met de gekozen leerweg. Tabel 4.2 laat voor het cohort dat in 2010-2011 in het derde leerjaar van de vmbo KB zat, per vmbosector zien in welk mbo-niveau en -leerweg de leerlingen in het schooljaar 2012-2013 instromen. Voor het geheel zijn de grote stromen die naar een mbo bol-opleiding niveau 3 (41\%) en naar een mbo bol-opleiding niveau 4 (36\%). Vanuit de vmbo-sector Economie stroomt een vergelijkbaar aandeel naar een mbo bol-niveau 3 opleiding en een iets hoger aandeel (43\%) naar een mbo bol-niveau 4 opleiding. Mbo bbl-opleidingen spelen geen significante rol voor de leerlingen vanuit de sector Economie. De verdeling over leerweg en instroom is voor de leerlingen uit de vmbo-sector Economie sterk vergelijkbaar met die uit de andere sectoren, met de uitzondering van de sector Techniek. Vanuit de sector Techniek stroomt bijna 30\% naar een mbo bbl-opleiding. Hierbij is ook duidelijk zichtbaar dat de inschrijving in eerste instantie op niveau 2 plaatsvindt.

TABEL 4.2 Instroom in leerweg en niveau: cohort 2010 (\%)

\begin{tabular}{|l|r|r|r|r|r|r|}
\hline & bol & bol & bol & bbl & bbl & bbl \\
niveau 2 & niveau 3 & niveau 4 & niveau 2 & niveau 3 & niveau 4 \\
\hline Economie & 10 & 42 & 43 & 3 & 3 & 0 \\
\hline Intersectoraal programma & 12 & 44 & 39 & 3 & 1 & 0 \\
\hline Landbouw & 13 & 50 & 27 & 7 & 4 & 0 \\
\hline Techniek & 17 & 20 & 36 & 23 & 3 & 0 \\
\hline Zorg \& Welzijn & 7 & 55 & 33 & 3 & 2 & 0 \\
\hline Vmbo KB & 11 & 41 & 36 & 8 & 3 & 0 \\
\hline
\end{tabular}

Bron: DUO (eigen berekening)

Een vergelijking van de doorstroom uit de vmbo KB-sector Economie naar een mboopleiding voor het cohort van 2010 (het cohort dat in 2012 in het mbo instroomde) en het cohort van 2015 (het cohort dat in 2017 in het mbo instroomde) toont een aantal interessante verschillen:

- Het aandeel dat in een mbo bol-niveau 2 opleiding instroomt, ligt voor het cohort van 2015 rond $5 \%$ (terwijl dit in 2010 nog 10\% was)

- Het aandeel dat in een mbo bol-niveau 3 opleiding instroomt, ligt voor het cohort van 2015 rond $34 \%$ (terwijl dit in 2010 nog $42 \%$ was)

- Het aandeel dat in een mbo bol-niveau 4 opleiding instroomt, ligt voor het cohort van 2015 rond 55\% (terwijl dit in 2010 nog $43 \%$ was).

Een vergelijkbare trend zien we ook voor het geheel van de vmbo KB-leerlingen. Met andere woorden, er lijkt een trend waarneembaar waarbij leerlingen uit de vmbo KB vaker op hoger niveau ingeschreven worden, waardoor stapelen minder noodzakelijk wordt. In hoeverre dit door de veranderingen in het financieringsstelsel (cascadestelsel) veroorzaakt word, ligt buiten het kader van dit onderzoek. 
Naast leerweg en niveau dienen de jongeren ook een keuze te maken voor een van de mogelijk beroepsopleidingen. Tabel 4.3 laat voor de instroom in mbo-niveau 3, het gekozen domein zien, Tabel 4.4 voor de instroom in mbo-niveau 4. Instroom in mboniveau 2 laten we verder buiten beschouwing, aangezien deze voor de leerlingen afkomstig uit de vmbo KB-sector Economie geen significante rol speelt.

Vanuit de centrale groep in dit onderzoek, namelijk de leerlingen die een opleiding in de vmbo-sector Economie volgen, is de instroom in een opleiding in het domein Economie en Administratie op mbo-niveau $333 \%$, en $18 \%$ in het domein Handel en Ondernemerschap. Naast deze twee domeinen kennen de domeinen Zorg \& Welzijn (11\%), Horeca en Bakkerij (8\%), Informatie en Communicatietechnologie (8\%) Toerisme en Recreatie (7\%) en Veiligheid en Sport (70\%) ook een relatief hoge instroom.

TABEL 4.3 Instroom in mbo-domein niveau 3: cohort 2010 (\%)

\begin{tabular}{|c|c|c|c|c|c|c|}
\hline & Economie & $\begin{array}{r}\text { Intersectoraal } \\
\text { programma }\end{array}$ & Landbouw & Techniek & $\begin{array}{r}\text { Zorg \& } \\
\text { Welzijn }\end{array}$ & Totaal \\
\hline Afbouw, hout en onderhoud & 0 & 0 & 1 & 7 & 0 & 1 \\
\hline $\begin{array}{l}\text { Ambacht, laboratorium en } \\
\text { gezondheidstechniek }\end{array}$ & 0 & 1 & 1 & 1 & 1 & 1 \\
\hline Bouw en infra & & 0 & 2 & 5 & 0 & 1 \\
\hline Economie en administratie & 33 & 9 & 3 & 5 & 3 & 11 \\
\hline Handel en ondernemerschap & 18 & 7 & 5 & 7 & 5 & 9 \\
\hline Horeca en bakkerij & 8 & 2 & 3 & 2 & 2 & 4 \\
\hline $\begin{array}{l}\text { Informatie en } \\
\text { communicatietechnologie }\end{array}$ & 8 & 10 & 4 & 15 & 1 & 6 \\
\hline Media en vormgeving & 1 & 1 & 1 & 5 & 0 & 1 \\
\hline Mobiliteit en voertuigen & 0 & 1 & 1 & 8 & & 1 \\
\hline Techniek en procesindustrie & 1 & 1 & 1 & 18 & & 3 \\
\hline Toerisme en recreatie & 7 & 6 & 3 & 2 & 5 & 5 \\
\hline $\begin{array}{l}\text { Transport, scheepvaart en } \\
\text { logistiek }\end{array}$ & 1 & 1 & 1 & 5 & 0 & 1 \\
\hline Uiterlijke verzorging & 3 & 3 & 6 & 1 & 11 & 6 \\
\hline Veiligheid en sport & 7 & 37 & 6 & 8 & 5 & 10 \\
\hline $\begin{array}{l}\text { Voedsel, natuur en leefomgeving } \\
\text { (EZ) }\end{array}$ & 2 & 3 & 42 & 8 & 3 & 9 \\
\hline Zorg \& welzijn & 11 & 18 & 22 & 5 & 64 & 32 \\
\hline
\end{tabular}

Bron: DUO (eigen berekening) 
TABEL 4.4 Instroom in mbo-domein niveau 4: cohort 2010 (\%)

\begin{tabular}{|c|c|c|c|c|c|c|}
\hline & Economie & $\begin{array}{r}\text { Intersectoraal } \\
\text { programma }\end{array}$ & Landbouw & Techniek & $\begin{array}{r}\text { Zorg \& } \\
\text { Welzijn }\end{array}$ & Totaal \\
\hline Afbouw, hout en onderhoud & 1 & 0 & 1 & 3 & 0 & 1 \\
\hline $\begin{array}{l}\text { Ambacht, laboratorium en } \\
\text { gezondheidstechniek }\end{array}$ & 1 & 1 & 1 & 1 & 1 & 1 \\
\hline Bouw en infra & 2 & 2 & 2 & 11 & 0 & 4 \\
\hline Economie en administratie & 32 & 14 & 7 & 3 & 5 & 14 \\
\hline Handel en ondernemerschap & 10 & 5 & 6 & 2 & 3 & 5 \\
\hline Horeca en bakkerij & 9 & 5 & 5 & 1 & 4 & 5 \\
\hline $\begin{array}{l}\text { Informatie en } \\
\text { communicatietechnologie }\end{array}$ & 4 & 7 & 2 & 4 & 0 & 4 \\
\hline Media en vormgeving & 10 & 19 & 13 & 16 & 6 & 12 \\
\hline Mobiliteit en voertuigen & 1 & 1 & 4 & 11 & 0 & 3 \\
\hline Techniek en procesindustrie & 2 & 3 & 5 & 34 & 0 & 10 \\
\hline Toerisme en recreatie & 4 & 4 & 3 & 1 & 5 & 4 \\
\hline Transport, scheepvaart en logistiek & 5 & 3 & 3 & 5 & 3 & 4 \\
\hline Uiterlijke verzorging & 0 & 1 & 1 & 0 & 2 & 1 \\
\hline Veiligheid en sport & 2 & 14 & 4 & 2 & 3 & 4 \\
\hline $\begin{array}{l}\text { Voedsel, natuur en leefomgeving } \\
\text { (EZ) }\end{array}$ & 2 & 2 & 24 & 3 & 1 & 4 \\
\hline Zorg \& welzijn & 16 & 21 & 20 & 4 & 66 & 27 \\
\hline
\end{tabular}

Bron: DUO (eigen berekening)

Kijken we naar de instroom op niveau 4, zien we wat de instroom in het domein Economie en Administratie wederom dat een op de drie afkomstig van de vmbo KB-sector Economie voor een opleiding in deze domein kiest. Het aandeel dat in het domein Handel en Ondernemerschap instroomt is met 10\% duidelijk kleiner dan op niveau 3. Naast de domeinen Zorg \& Welzijn ( $16 \%$ instroom vanuit de vmbo-sector Economie) en Horeca en Bakkerij zien we op niveau 4 ook dat 10\% van de vmbo sector Economie leerlingen instromen in de domein Media en Vormgeving.

Tabel 4.5 vat de instroom in de twee economische domeinen over de jaren heen vanuit de vmbo KB-sector Economie samen. Wat de instroom in het domein Economie en Administratie betreft, zien we op niveau 4 een tegengestelde trend dan op niveau 3. Terwijl op niveau 3 het aandeel dat in dit domein instroomt in de onderzochte periode daalt van boven de $30 \%$ naar $20 \%$, zien we op niveau 4 een lichte stijging. Het aandeel dat in het domein Handel en Ondernemerschap op niveau 3 instroomt daalt eveneens terwijl dit op niveau 4 relatief stabiel blijft. De consequentie van deze ontwikkelingen is dat op niveau 3 de verwante doorstroom vanuit de vmbo KB-sector Economie daalt van $50 \%$ naar zo'n $30 \%$. Op niveau 4 blijft de verwante doorstroom schommelen rond de $45 \%$. 
TABEL 4.5 Instroom in economische mbo-domeinen over de jaren vanuit vmbo KB Economie (\%)

\begin{tabular}{|l|r|r|r|r|r|r|}
\hline Niveau 3 & 2010 & 2011 & 2012 & 2013 & 2014 & 2015 \\
\hline Economie en Administratie & 33 & 31 & 25 & 24 & 21 & 20 \\
\hline Handel en Ondernemerschap & 18 & 19 & 20 & 16 & 16 & 12 \\
\hline Ander domein & 50 & 51 & 55 & 60 & 63 & 69 \\
\hline Niveau 4 & & & & & \\
\hline Economie en Administratie & 32 & 31 & 35 & 31 & 37 & 36 \\
\hline Handel en Ondernemerschap & 10 & 11 & 10 & 11 & 8 & 9 \\
\hline Ander domein & 59 & 58 & 55 & 57 & 55 & 55 \\
\hline
\end{tabular}

Bron: DUO (eigen berekening)

Wat de verwante doorstroom betreft, is de vraag is nu of er ook in de vmbo KB verschillen waarneembaar zijn tussen autochtone jongeren en jongeren met een niet-westerse migratieachtergrond, en tussen meisjes en jongens. Van de jongeren met een nietwesterse migratieachtergrond die in het schooljaar 2010-2011 in het derde leerjaar van de vmbo KB-sector Economie zaten, begon 46\% van degenen die in een mbo-opleiding op niveau 3 of 4 instroomde, met een opleiding in het domein Economie en Administratie en $12 \%$ met een opleiding in het domein Handel en Ondernemerschap. Onder de autochtone jongeren zijn de aandelen respectievelijk $23 \%$ en $15 \%$. Vergelijkbaar met de uitkomst voor de jongeren uit de vmbo BB, zien we dat ook hier de groep jongeren met een niet-westerse migratieachtergrond aanzienlijk vaker een verwante doorstroom kiest. De verschillen tussen jongens en meisjes zijn minimaal wat het aandeel betreft dat een verwante doorstroom kiest. Echter is ook hier zichtbaar dat de alternatieven buiten deze twee mbo-domeinen voor jongens en meisjes verschillen, aangezien meisjes relatief vaak doorstromen naar het mbo-domein Zorg \& Welzijn (24\%) terwijl jongeren relatief vaak kiezen voor Informatie en Communicatietechnologie (11\%) en Veiligheid en Sport (7\%).

De twee economische domeinen bieden op niveau 3 en 4 keuze uit verschillende beroepsopleidingen. Op niveau 3 (zie Tabel 4.6) zien we dan ook dat in het domein Economie en Administratie, drie beroepsopleidingen een aandeel boven de $10 \%$ kennen, namelijk'Financieel administratieve beroepen, 'Commercie' en 'Secretariële beroepen'. In het domein Handel en Ondernemerschap speelt op niveau 3 de beroepsopleiding 'Advies en leiding in verkoop' duidelijk de hoofdrol. Op niveau 4 zien we in beide domeinen een viertal beroepsopleidingen een instroom boven de 10\%. In het domein Economie en Administratie zijn dit de beroepsopleidingen 'Juridisch-administratieve beroepen', 'Financieel-administratieve beroepen', 'Commercie' en 'Marketing, communicatie en evenementen'. In het domein Handel en Ondernemerschap zijn dit de beroepsopleidingen 'Management retail', 'Ondernemerschap retail', 'Interieuradvies' en 'Fashion, design \& productmanagement'. 
TABEL 4.6 Instroom in beroepsopleidingen: cohort 2010 (\%)

\begin{tabular}{|c|c|c|}
\hline & Economie en Administratie & Handel en Ondernemerschap \\
\hline \multicolumn{3}{|l|}{ Niveau 3} \\
\hline Advies en leiding in de verkoop & & 96 \\
\hline Commercie & 37 & \\
\hline Financieel administratieve beroepen & 49 & \\
\hline Secretariële beroepen & 14 & \\
\hline \multicolumn{3}{|l|}{ Niveau 4} \\
\hline Commercie & 25 & \\
\hline Fashion design \& productmanagement & & 11 \\
\hline Financieel administratieve beroepen & 21 & \\
\hline Financiële dienstverlening & 2 & \\
\hline Interieuradvies & & 19 \\
\hline Juridisch-administratieve beroepen & 27 & \\
\hline Management Retail & & 45 \\
\hline Marketing, communicatie en evenementen & 19 & \\
\hline Mode/maatkleding & & 2 \\
\hline Ondernemerschap Retail & & 22 \\
\hline Secretariële beroepen & 6 & \\
\hline
\end{tabular}

Bron: DUO (eigen berekening)

Instroom in een mbo-opleiding is stap één, de opleiding succesvol afronden is stap twee. Volgen we het cohort dat in het schooljaar 2010-2011 in het derde leerjaar van de kaderberoepsgerichte leerweg zat tot en met het schooljaar 2017-2018, dan zien we dat $14 \%$ nog geen mbo-diploma heeft behaald (zie Tabel 4.7). De verschillen tussen sectoren zijn daarbij relatief groot. Zo heeft $11 \%$ van de leerlingen die vanuit de vmbo-sector Techniek in het mbo zijn ingestroomd nog geen diploma behaald. Bij de jongeren uit de sector Economie en de Intersectorale sector is dit $18 \% .29 \%$ van de jongeren die nog geen mbodiploma heeft behaald, heeft in het schooljaar 2018-2019 nog een geldige inschrijving in het Nederlandse onderwijssysteem, voor zover door DUO geregistreerd. Hierbij doen zich geen duidelijke verschillen voor tussen jongeren afkomstig uit de vmbo KB-sector Economie en de andere sectoren.

Tussen 9\% (Zorg \& Welzijn, Economie) en 21\% (Techniek) heeft tot nu toe maximaal een niveau 2-diploma behaald. Het aandeel met een niveau 4-diploma als hoogst behaald diploma, is het hoogst voor de sector Economie (49\%) en het laagst voor de sector Techniek (26\%). Hierbij dient er bij de sector Techniek rekening gehouden te worden dat zij het vaakst via het mbo bbl de opleiding volgen, en daarom het vaakst via een opstapeling van diploma's de opleiding doorlopen ${ }^{7,8}$.

7 Jongeren die in het vmbo LWOO hadden, doen het iets beter. Van hen heeft 15\% nog geen diploma, $8 \%$ een niveau 2-diploma, $23 \%$ een niveau 3-diploma en $53 \%$ een niveau 4-diploma. Voor jongeren zonder LWOO zijn de cijfers respectievelijk $19 \%, 10 \%, 24 \%$ en $47 \%$.

8 Daarnaast kan meespelen dat dat de nominale opleidingsduur van niveau 4 techniekopleidingen in de regel een jaar langer is dan van andere opleidingen. 
TABEL 4.7 Hoogst behaald mbo-diploma tot en met schooljaar 2017-2018 indien instroom in mbo in 2012: cohort 2010 (\%)

\begin{tabular}{|l|r|r|r|r|r|}
\hline & (Nog) geen mbo- & & & \\
& diploma & Niveau 1 & Niveau 2 & Niveau 3 & Niveau 4 \\
\hline Economie & 18 & 0 & 9 & 24 & 49 \\
\hline Intersectoraal programma & 18 & 0 & 13 & 26 & 43 \\
\hline Landbouw & 12 & 0 & 15 & 37 & 36 \\
\hline Techniek & 11 & 0 & 21 & 32 & 26 \\
\hline Zorg \&Welzijn & 12 & 0 & 9 & 33 & 46 \\
\hline Alle sectoren & 14 & 0 & 13 & 30 & 43 \\
\hline
\end{tabular}

Bron: DUO (eigen berekening)

Figuur 4.5 laat zien of er, vergelijkbaar met de resultaten voor de vmbo BB, verschillen zichtbaar zijn tussen jongeren met een niet-westerse migratieachtergrond en jongeren zonder migratieachtergrond. Ook hier zien we grotere heterogeniteit onder jongeren met een niet-westerse migratieachtergrond. Het aandeel leerlingen met een nietwesterse migratieachtergrond dat (nog) geen mbo-diploma heeft behaald, is met $23 \%$ (zowel voor vmbo KB als voor de sector Economie) aanzienlijk hoger dan onder de autochtone jongeren (12\% [vmbo KB] en 15\% [sector Economie]). Hiertegenover staat dat het aandeel dat tot en met het schooljaar 2017-2018 al een mbo-niveau 4 diploma heeft behaald onder de groep jongeren afkomstig uit de vmbo KB-sector Economie met een niet-westerse migratieachtergrond $55 \%$ is, wat zo'n $10 \%$-punt hoger ligt dan onder de autochtone jongeren. 
FIGUUR 4.5 Hoogst behaald mbo-diploma (cohort 2010) naar etnische achtergrond

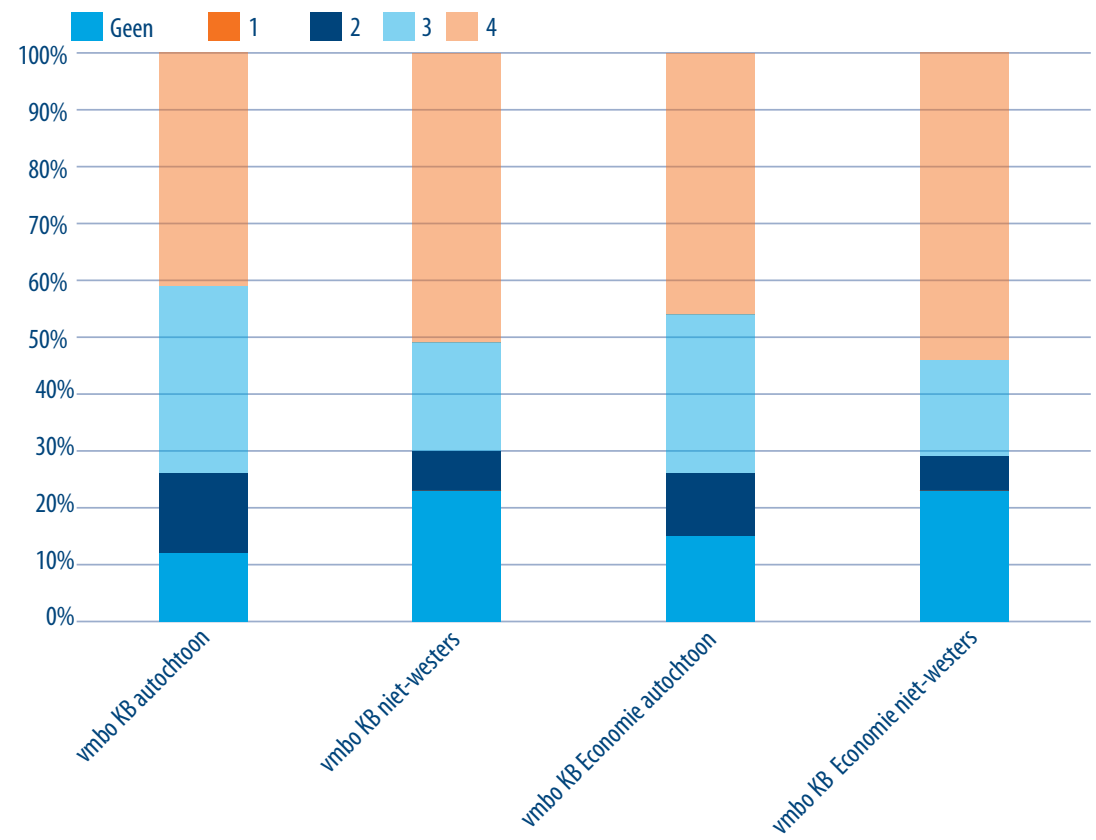

Bron: DUO (eigen berekening)

Tot slot stelt zich de vraag of het domein waarin men het mbo-niveau 3 of 4 diploma behaalt, hetzelfde is als die waarin men in eerste instantie instroomde (zie Tabel 4.8). Ook hier zijn de resultaten sterk vergelijkbaar met die voor de vmbo BB-sector Economie. $83 \%$ (86\%) van de gediplomeerden van het domein Economie en Administratie (Handel en Ondernemerschap) is ook vanuit de vmbo KB-sector Economie in dit domein ingestroomd. Nog eens 7\% (5\%) van het domein Economie en Administratie (Handel en Ondernemerschap) wisselt tussen instroom en diploma tussen de twee economische mbo-domeinen.

TABEL 4.8 Mbo-domein instroom versus mbo-domein niveau 3/4 diploma: vmbo Economie, cohort $2010(\%)$

\begin{tabular}{l|l|r|r|r|}
\hline $\begin{array}{l}\text { Mbo-domein: } \\
\text { Diploma niveau } \\
3 / 4\end{array}$ & $\begin{array}{l}\text { Economie en } \\
\text { Administratie }\end{array}$ & 83 & $\begin{array}{r}\text { Handel en } \\
\text { Ondernemerschap }\end{array}$ & $\begin{array}{r}\text { Andere domein } \\
\text { Handel en } \\
\text { Ondernemerschap }\end{array}$ \\
\cline { 2 - 4 } & Ander domein & 7 & 5 & 4 \\
\hline & 10 & 86 & 9 \\
\hline
\end{tabular}

Bron: DUO (eigen berekening) 


\section{VMBO GEMENGDE EN THEORETISCHE LEERWEG}

Naast de twee beroepsgerichte leerwegen kent het vmbo ook de gemengde en de theoretische leerweg. De gemengde leerweg, qua aantallen duidelijk de kleinere leerweg van de twee, kent vergelijkbaar met de beroepsgerichte leerweg een indeling in sectoren. In het voorliggende hoofdstuk is echter ervoor gekozen om de gemengde en theoretische leerwegen gezamenlijk te beschouwen zonder daarbij een onderscheid in sectoren te maken. Reden hiervoor is dat er tussen het derde en het vierde leerjaar relatief veel wisselingen tussen de twee leerwegen plaatsvinden. Daarnaast bieden beide leerwegen in principe een vergelijkbare basis voor de vervolgopleidingen, namelijk voor de instroom in mbo-niveau 4 opleidingen dan wel in de havo. Het hoofdstuk is wederom als volgt opgebouwd; in eerste instantie (Paragraaf 5.1) staan we stil bij het aantal leerlingen in de twee leerwegen en enkele kenmerken van deze leerlingen. In Paragraaf 5.2 volgen we de instroom in een mbo-opleiding en bespreken we hun succes hierin.

\subsection{Het derde leerjaar}

Figuur 5.1 laat het aantal leerlingen in het derde jaar van de gemengde en de theoretische leerweg zien (vmbo GL/TL). Het aantal leerlingen in de gemengde leerweg stijgt over de jaren van ongeveer 14.500 tot iets boven de 17.000. In de theoretische leerweg stijgt in dezelfde periode het aantal van ongeveer 32.000 tot 41.000 . Daarmee stijgt het totale aantal leerlingen in deze twee leerwegen van ongeveer 46.000 naar 58.000 in de onderzochte periode. De verhouding tussen de gemengde en de theoretische leerweg blijft daarbij over de onderzochte periode relatief constant rond 30/70. 
FIGUUR 5.1 Aantal leerlingen in het derde leerjaar vmbo GL/TL

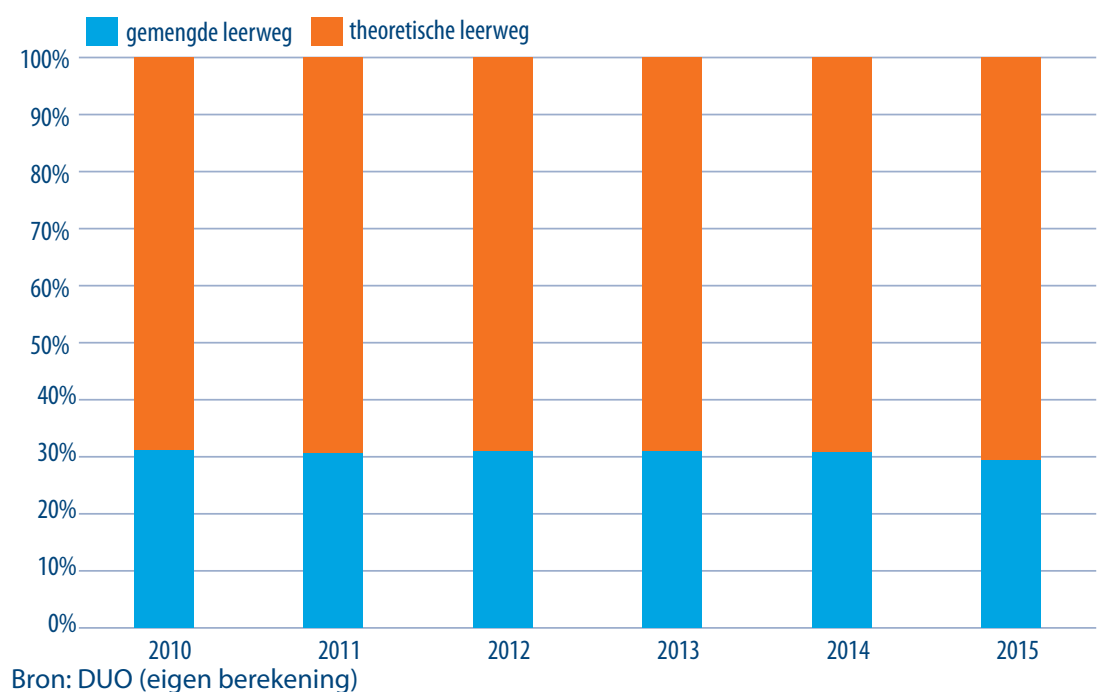

In tegenstelling tot de beroepsgerichte leerwegen zien we voor deze twee leerwegen in de onderzochte periode geen grote verschuivingen van het aandeel leerlingen met leerwegondersteuning (LWOO) (rond de 5\%), het aandeel meisjes (50\%), en het aandeel leerlingen met een niet-westerse migratieachterond (16\%).

\subsection{Van vmbo GL/TL naar mbo}

De theoretische en de gemengde leerweg bereiden leerlingen voor op een mbo-niveau 4 opleiding. Wat de doorstroom naar deze mbo-opleidingen betreft, is het van belang om in in het onderzoek te focussen op de groep die regulier binnen de geselecteerde vmbo-leerweg de opleiding volgt/afrondt (de'main stream' groep).

In Box 5.1 laten we zien wat de keuzes zijn die wij daarbij maken, en hoe wij zo de groep bekomen waarvan we uiteindelijk de doorstroom naar het mbo en het succes in het mbo vaststellen. We doen dit wederom aan de hand van het cohort van 2010. 
- $\quad$ In het cohort van 2010 zijn $\mathbf{4 6 . 4 8 5}$ jongeren ingeschreven in het derde leerjaar van de vmbo GL (14.467) of vmbo TL (32.018).

- $\quad$ In 2011 zijn van de $\mathbf{4 6 . 4 8 5}$ jongeren $\mathbf{4 4 . 0 0 2}$ ingeschreven in het vierde leerjaar. $\mathbf{6 . 2 2 4}$ jongeren zijn in de vmbo GL ingeschreven en $\mathbf{3 7 . 7 7 8}$ in de vmbo TL.

- $\quad$ Van de $\mathbf{4 4 . 0 0 2 ~ j o n g e r e n ~ h e b b e n ~ t o t ~ 2 0 1 2 , ~} \mathbf{4 2 . 2 4 3}$ een diploma GL of TL behaald. $\mathbf{5 . 6 9 2}$ jongeren hebben een GL-diploma behaald en $\mathbf{3 6 . 5 5 1}$ jongeren een TL-diploma.

Van de $\mathbf{4 2 . 2 4 3}$ jongeren zijn er in 2012 32.437 jongeren in het mbo geldig ingeschreven.

Voordat we focussen op de 'main stream' groep, is het interessant om kort stil te staan bij de groep die we in dit hoofdstuk niet beschouwen. Van de ongeveer 14.000 jongeren die buiten de selectie vallen, heeft tot en met het schooljaar 2018-2019, 35\% een havodiploma behaald en nog eens $2 \%$ een vwo-diploma. $27 \%$ heeft een mbo-niveau 4 diploma behaald en 10\% een mbo-niveau 3. Tegelijkertijd zien we dat $18 \%$ (zo'n 2.500 jongeren) tot en met het schooljaar 2017-2018 nog geen diploma buiten het vmbo heeft behaald. Van deze laatste groep heeft overigens zo'n 30\% (744 jongeren) ook geen vmbo-diploma behaald.

Tabel 5.1 laat zien in welke leerweg en in welk niveau de leerlingen in het mbo instromen. Gezien we bij de leerlingen van de vmbo KB tussen 2010 en 2015 redelijk wat verschillen vonden, presenteren we hier onmiddellijk de cijfers voor 2010 en 2015. Niet verrassend, stroomt het grootste deel door naar een mbo bol-niveau 4 opleiding. Maar ook hier zien we dat in vergelijking tot 2010, in 2015 het aandeel dat doorstroomt naar het mbo bolniveau 4 toeneemt en het aandeel dat doorstroomt naar het mbo bol-niveau 3 afneemt. Mbo bbl-opleidingen worden slechts marginaal gekozen.

TABEL 5.1 Instroom in mbo-leerweg en -niveau (\%)

\begin{tabular}{|r|r|r|r|r|r|r|r|r|r|}
\hline & bol 1 & bol 2 & bol 3 & bol 4 & bbl 1 & bbl2 & bbl 3 & bbl 4 \\
\hline 2010 & 0 & 3 & 17 & 76 & 0 & 2 & 1 & 0 \\
\hline 2015 & 0 & 2 & 8 & 87 & 0 & 1 & 2 & 0 \\
\hline
\end{tabular}

Bron: DUO (eigen berekening)

In wat volgt focussen we op de instroom in een mbo-niveau 3 of mbo-niveau 4 opleiding. Tabel 5.2 laat zien in welke mbo-domeinen de leerlingen instromen (cohort 2010) en in hoeverre de instroom in de twee economische mbo-domeinen varieert over de jaren heen. 
TABEL 5.2 Instroom in mbo-domein: cohort 2010 (\%)

\begin{tabular}{|l|r|r|}
\hline & Niveau 3 & Niveau 4 \\
\hline Afbouw, hout en onderhoud & 1 & 1 \\
\hline Ambacht, laboratorium en gezondheidstechniek & 1 & 2 \\
\hline Bouw en infra & 1 & 3 \\
\hline Economie en administratie & 19 & 17 \\
\hline Handel en ondernemerschap & 9 & 8 \\
\hline Horeca en bakkerij & 4 & 5 \\
\hline Informatie en communicatietechnologie & 6 & 5 \\
\hline Media en vormgeving & 2 & 10 \\
\hline Mobiliteit en voertuigen & 1 & 1 \\
\hline Techniek en procesindustrie & 2 & 6 \\
\hline Toerisme en recreatie & 4 & 3 \\
\hline Transport, scheepvaart en logistiek & 2 & 3 \\
\hline Uiterlijke verzorging & 8 & 1 \\
\hline Veiligheid en sport & 19 & 4 \\
\hline Voedsel, natuur en leefomgeving & & 3 \\
\hline Voedsel, natuur en leefomgeving (EZ) & 20 & 6 \\
\hline Zorg en welzijn & & 27 \\
\hline Bron: DUO (eigen berekening) & 20 & 2 \\
\hline
\end{tabular}

Bron: DUO (eigen berekening)

Tabel 5.3 laat zien dat de instroom over de jaren sterk afneemt voor het domein Economie en Administratie op niveau 3. Dit komt door een sterke daling tussen 2011 en 2013. Op niveau 4 blijft de verdeling over de jaren heen relatief stabiel.

TABEL 5.3 Instroom in mbo-domein: 2010 - 2015 (\%)

\begin{tabular}{|l|r|r|r|r|r|r|}
\hline Niveau 3 & 2010 & 2011 & 2012 & 2013 & 2014 \\
\hline Economie en administratie & 19 & 21 & 9 & 8 & 5 & 3 \\
\hline Handel en ondernemerschap & 9 & 9 & 8 & 7 & 6 & 5 \\
\hline Andere domein & 72 & 70 & 83 & 85 & 89 & 92 \\
\hline Niveau 4 & & & & & \\
\hline Economie en administratie & 17 & 16 & 16 & 16 & 20 & 20 \\
\hline Handel en ondernemerschap & 8 & 7 & 8 & 8 & 5 & 5 \\
\hline Andere domein & 75 & 77 & 76 & 76 & 75 & 75 \\
\hline
\end{tabular}

Bron: DUO (eigen berekening)

De vraag stelt zich of we ook in de vmbo GL/TL verschillen zien wat de doorstroom naar de twee economische mbo-domeinen betreft, tussen autochtone jongeren en jongeren met een niet-westerse migratieachtergrond, en tussen jongens en meisjes. Van de jongeren met een niet-westerse migratieachtergrond die in het schooljaar 20102011 in het derde leerjaar van de vmbo GL/TL zaten, begon 35\% van degenen die in een mbo-opleiding niveau 3 of 4 instroomde, met een opleiding in het domein Economie en Administratie en 10\% met een opleiding in de domein Handel en Ondernemerschap. Onder de autochtone jongeren is dit respectievelijk $14 \%$ en $7 \%$. Vergelijkbaar met de uitkomst 
onder de jongeren uit de andere leerwegen, zien we dat ook hier de groep jongeren met een niet-westerse migratieachtergrond aanzienlijk vaker voor een van deze twee mbodomeinen kiest. De verschillen tussen jongens en meisjes zijn kleiner, wat het aandeel betreft dat een verwante doorstroom kiest. Zo kiest 20\% van de jongens en $15 \%$ van de meisjes voor het mbo-domein Economie en Administratie, en kiest $8 \%$ van de jongens en $7 \%$ van de meisjes een opleiding in het domein Handel en Ondernemerschap.

TABEL 5.4 Instroom in beroepsopleidingen: cohort 2015 (\%)

\begin{tabular}{|l|r|r|}
\hline Niveau 3 & Economie en Administratie & Handel en Ondernemerschap \\
\hline Advies en leiding in de verkoop & 18 & 97 \\
\hline Commercie & 65 & \\
\hline Financieel administratieve beroepen & 17 & 3 \\
\hline Mode/maatkleding & & \\
\hline Secretariële beroepen & 29 & \\
\hline Niveau 4 & 20 & 11 \\
\hline Commercie & 1 & \\
\hline Fashion design \& productmanagement & & \\
\hline Financieel administratieve beroepen & 18 & \\
\hline Financiële dienstverlening & & \\
\hline Interieuradvies & 25 & 41 \\
\hline Juridisch-administratieve beroepen & & \\
\hline Management Retail & 6 & \\
\hline Marketing, communicatie en evenementen & & \\
\hline Mode/maatkleding & & \\
\hline Ondernemerschap Retail & & \\
\hline Secretariële beroepen & & \\
\hline
\end{tabular}

Bron: DUO (eigen berekening)

Tot slot toont Tabel 5.4 welke beroepsopleidingen de leerlingen kiezen (op basis van het cohort van 2015). De resultaten zijn daarbij sterk vergelijkbaar met onze bevindingen voor de vmbo KB.

Instroom in het mbo is stap één, het diploma behalen is stap twee. Van de groep leerlingen die we vanaf het schooljaar 2010-2011 tot en met het schooljaar 2017-2018 volgen, heeft $72 \%$ in deze periode een mbo-niveau 4 diploma en nog eens $13 \%$ een mbo-niveau 3 diploma behaald. Van de overige 15\% heeft 11\%-punt nog geen enkel mbo-diploma behaald en heeft 4\%-punt een mbo-niveau 2 diploma. Van de 3.680 leerlingen die nog geen mbo-diploma hebben behaald, heeft $12 \%$ in de tussentijds een havo-diploma behaald en nog eens 1\% zelfs een vwo-diploma. Zij zijn blijkbaar vanuit het mbo overgestapt naar de havo/vwo. Van de overige 3.220 jongeren heeft $35 \%$ in het schooljaar 2018-2019 een geldige inschrijving in het Nederlandse onderwijssysteem, voor zover door DUO geregistreerd. 
Analyseren we het succes wat het behalen van een mbo-diploma betreft, tussen de groep autochtone jongeren en de groep jongeren met een niet-westerse migratieachtergrond (zie Figuur 5.2), dan zien we dat de tweede groep, vergelijkbaar met onze resultaten voor de beroepsgerichte leerwegen, een hogere kans heeft om nog geen mbo-diploma behaald te hebben. Verschillend met de beroepsgerichte leerwegen, zien we echter niet dat deze groep ook vaker een mbo-niveau 4 diploma behaalt. Bij beide groepen ligt het percentage rond de $73 \%$.

FIGUUR 5.2 Mbo-diploma naar etnische achtergrond: cohort 2010 (\%)

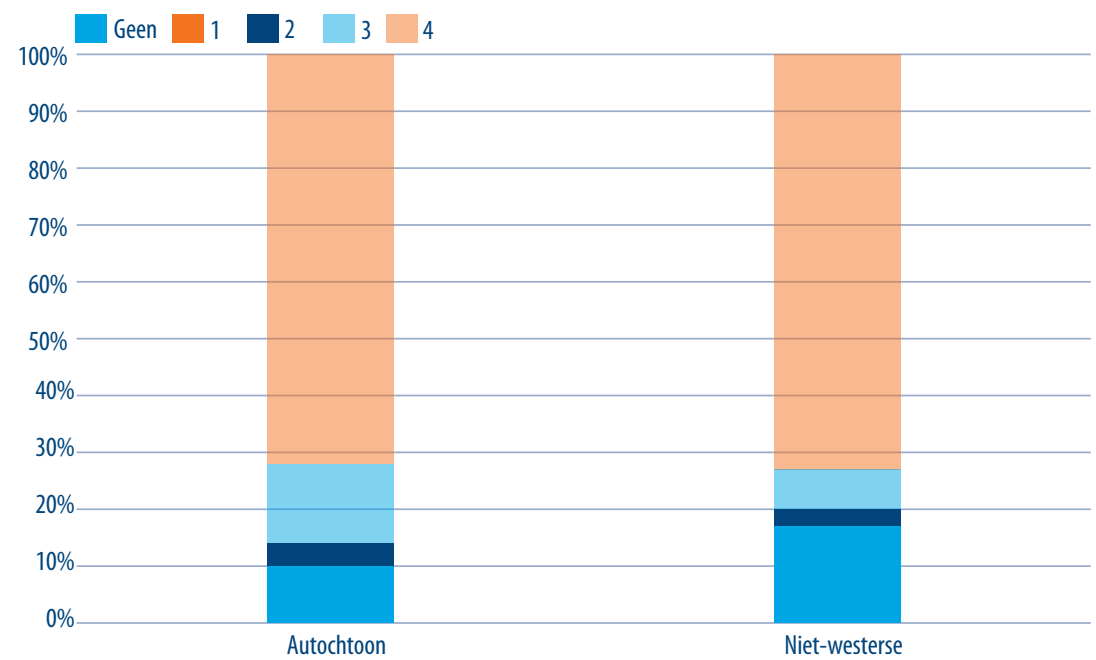

Bron: DUO (eigen berekening)

Tot slot stellen we de vraag of men het diploma op niveau 3 en 4 ook in het mbo-domein behaalt waar men oorspronkelijk is ingestroomd na het vmbo. Vergelijkbaar met de andere vmbo-leerwegen, zien we dat het grootse deel aan het domein trouw blijft en indien men van domein verandert, men vaak ook de economische domeinen verlaat.

TABEL 5.5 Mbo-domein instroom versus mbo-domein mbo-niveau 3/4 diploma (\%)

\begin{tabular}{|l|l|r|r|r|}
\hline & & Economie en Administratie & Handel en Ondernemerschap & Ander domein \\
\hline Mbo-domein: & Economie en Administratie & 86 & 5 & 3 \\
\hline $\begin{array}{l}\text { Diploma niveau } \\
3 / 4\end{array}$ & Handel en Ondernemerschap & 5 & 85 & 2 \\
\cline { 2 - 5 } & Ander domein & 9 & 10 & 95 \\
\hline & Totaal & 100 & 100 & 100 \\
\hline
\end{tabular}

Bron: DUO (eigen berekening) 


\section{MBO-NIVEAU 4 DIPLOMA: DOORSTROOM NAAR HBO}

Van de leerlingen die in 2012 een mbo-niveau 4 diploma hebben behaald, heeft tot en met het schooljaar 2017-2018 ondertussen één op de drie een diploma in het hoger onderwijs behaald. Hierbij doen zich duidelijke verschillen voor tussen jongeren afhankelijk van de leerweg die ze voorafgaand aan de mbo-opleiding in het vmbo gevolgd hebben (zie Figuur 6.1). Zo heeft $41 \%$ van de 24.038 jongeren uit de vmbo TL een diploma in het hoger onderwijs behaald. Voor 28\%-punt hiervan is het een propedeuse, voor 12\%-punt een bachelorsdiploma en voor 1\%-punt een Ad-diploma. De jongeren uit de vmbo GL staan op de tweede plek. Van de 3.827 jongeren heeft 23\%-punt een propedeuse, 11\% -punt een bachelorsdiploma en 1\%-punt een Ad-diploma. In totaal heeft 35\% van deze groep een diploma in het hoger onderwijs behaald. Van de 11.522 jongeren die oorspronkelijk in de vmbo KB hun diploma hebben behaald, is het nog steeds meer dan een op de vier die tot en met het schooljaar 2017-2018 een diploma in het hoger onderwijs heeft behaald. Ook hier is dit voornamelijk een propedeuse (18\%-punt), een bachelorsdiploma (8\%-punt) of een Ad-diploma (1\%-punt). Tot slot zien we dat zo'n 14\% van de 3.572 gediplomeerden die in 2012 een mbo-niveau 4 diploma behaald hebben, en die hun schoolcarrière in het voortgezet onderwijs in de vmbo BB zijn gestart, tot en met het schooljaar 2017-2018 een diploma in het hoger onderwijs heeft behaald (10\%-punt een propedeuse en $4 \%$-punt een bachelorsdiploma). Als we deze groep mbo 4-gediplomeerden langer volgen, dan zal naar verwachting het aandeel met een bachelorsdiploma verder stijgen, terwijl het aandeel met een propedeuse zal afnemen. 
FIGUUR 6.1 Diploma in Hoger Onderwijs na behalen van mbo-niveau 4 diploma in 2012-2013 (\%)

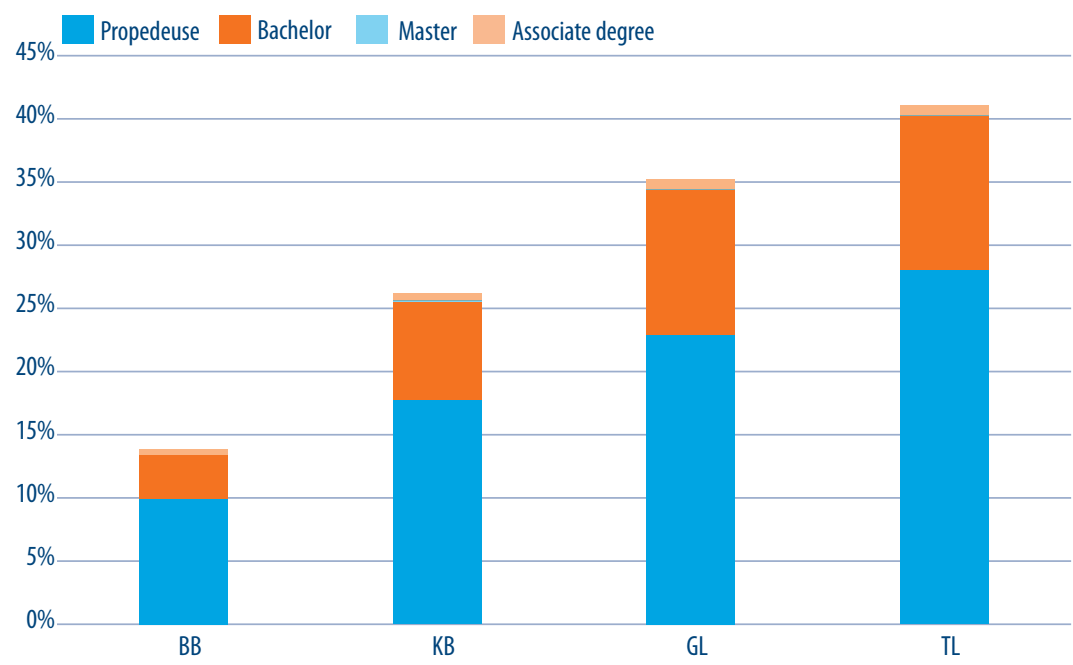

Bron: DUO (eigen berekening)

Figuur 6.2 laat zien dat de studenten afkomstig uit het mbo-niveau 4 domein Economie en Administratie vaker een hoger onderwijs diploma hebben behaald dan de studenten afkomstig uit het domein Handel en Ondernemerschap. ${ }^{9}$ Ook doen ze het in vergelijking met de totale groep mbo-niveau 4 gediplomeerden beter. Het verschil zit vooral in het hoger aandeel met een propedeuse. Het aandeel met een bachelordiploma ligt namelijk bij alle drie onderscheiden groepen rond $10 \%$. Nadere analyses laten zien dat binnen de 2 economische domeinen er in het algemeen geen grote verschillen tussen in het doorstroomsucces zich voordoen tussen autochtone jongeren en jongeren met een niet-westerse migratieachtergrond. In beide groepen heeft zo'n 38-39\% in de tussentijd een diploma in het hoger onderwijs behaald. Wel is zichtbaar dat het aandeel dat in de tussentijd al een bachelorsdiploma heeft behaald onder de groep autochtone jongeren zo'n 3\%-punt hoger ligt dan onder de groep jongeren met een niet-westerse migratieachtergrond. De latere groep jongeren heeft daartegenover vaker eerst een propedeuse behaald. wat eerder voor alle gediplomeerden van het mbo niveau 4 is gepresenteerd. 
FIGUUR 6.2 Diploma in Hoger Onderwijs na behalen van mbo-niveau 4 diploma in 2012-2013 (\%)

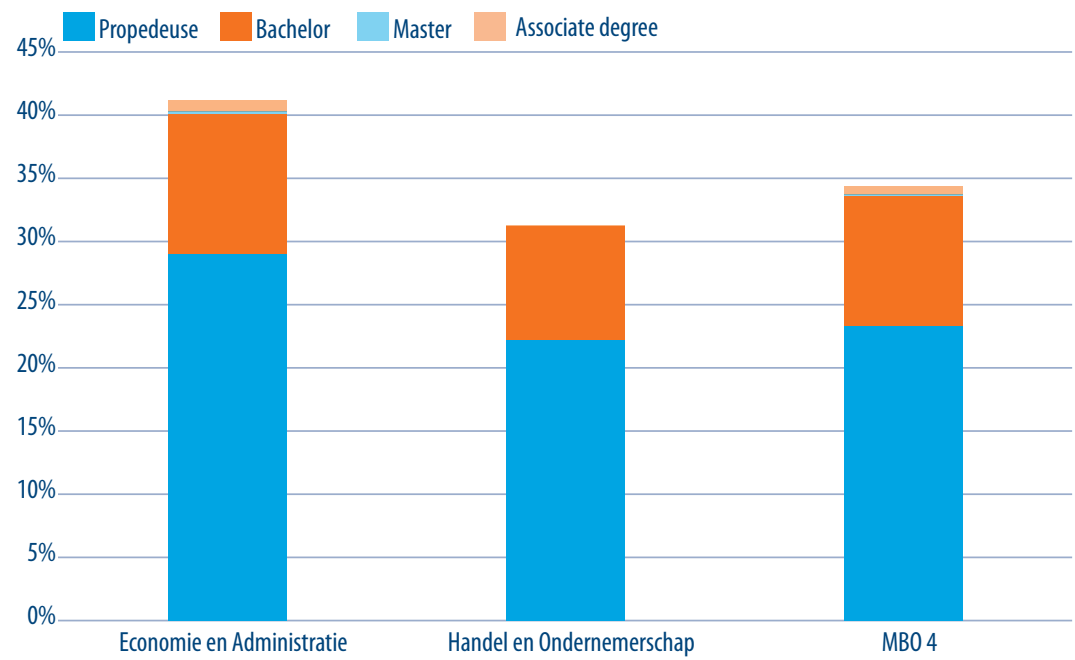

Bron: DUO (eigen berekening)

Tot slot laat Figuur 6.3 voor degenen die tot nu toe een diploma in het hoger onderwijs hebben behaald, zien in welke sector dit diploma is behaald. Niet verrassend, is dit zowel voor de studenten afkomstig uit het mbo-domein Economie en Administratie als uit Handel en Ondernemerschap, in twee derden van de gevallen een diploma in de sector Economie. Voor de groep afkomstig uit het domein Economie en Administratie, speelt daarnaast de sector Gedrag en Maatschappij een grote rol (21\%). Deze sector is ook belangrijk in het domein Handel en Ondernemerschap belangrijk (12\%) maar bij deze groep zien we ook een relatief hoog aandeel diploma's in de sector Techniek. 
FIGUUR 6.3 Sector van hbo-diploma, na behalen van mbo-niveau 4 diploma in 2012-2013 (\%)

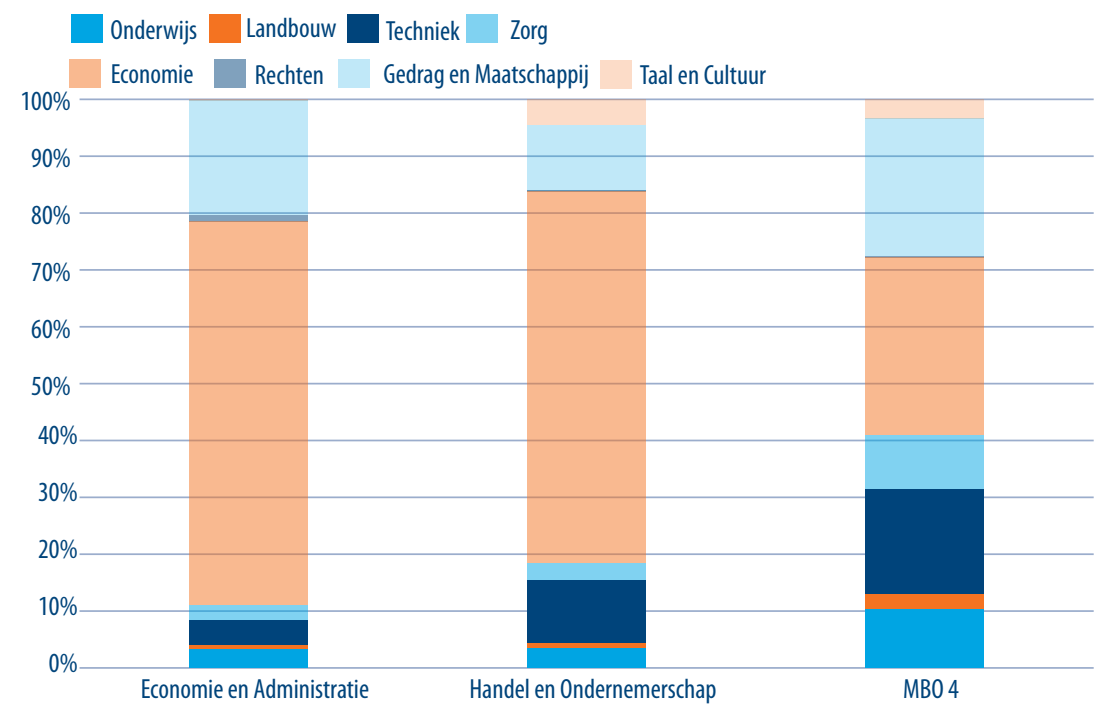

Bron: DUO (eigen berekening) 


\section{ARBEIDSMARKTRELEVANTIE}

Tot zover lag in dit rapport de nadruk op de onderwijsloopbaan van vmbo-leerlingen. Daarbij stond de vraag centraal of jongeren die een administratieve vmbo- dan wel mbo-opleiding volgden. Aangezien deze opleidingen voorbereiden op de arbeidsmarkt, willen we dus weten hoe het de jongeren die in een administratieve opleiding een diploma behalen, vergaat op de arbeidsmarkt. Tot slot van dit rapport, staan we in dit hoofdstuk dan ook stil bij de intrede op de arbeidsmarkt. We doen dit in drie stappen. In de eerste stap (Paragraaf 7.1) stellen we de vraag welk deel van de gediplomeerden van een mbo-administratieve opleiding, een jaar na het behalen van het diploma, werk voor minimaal 12 uur bezit. In de tweede stap (Paragraaf 7.2) kijken we op basis van de BVE-Monitor naar een aantal aanvullende arbeidsmarktkenmerken, in Paragraaf 7.3 doen we dit voor de afgestudeerden van het hbo. Tot slot, kijken we naar de nadere toekomst en bespreken op basis van het AIS van ROA wat de verwachte arbeidsmarktkansen tot 2022 zijn (Paragraaf 7.4).

\subsection{Arbeidsmarkt van mbo-gediplomeerden: Het vinden van werk}

Tabel 7.1 laat op basis van het driejarenbestand (2012/2013 - 2014/2015) van het CBS het aandeel gediplomeerden zien dat niet meer in het onderwijs zit en dat ruim een jaar na diplomering minimaal 12 uur per week werkzaam is..$^{10}$

10 In dit hoofdstuk focussen we op jongeren uit de bol-opleidingen. Tabel S.1 in de statistische bijlage bevat deze informatie ook voor de bbl-opleidingen. 
TABEL 7.1 Aandeel dat minimaal 12 uur werkzaam is: gediplomeerde uitstroom mbo-bol (\%)

\begin{tabular}{|l|r|r|}
\hline Domein & Niveau & Minimaal 12 uur werkzaam \\
\hline Economie en Administratie & 2 & 51 \\
\hline Handel en Ondernemerschap & 2 & 55 \\
\hline Economie en Administratie & 3 & 70 \\
\hline Handel en Ondernemerschap & 3 & 71 \\
\hline Economie en Administratie & 4 & 80 \\
\hline Handel en Ondernemerschap & 4 & 78 \\
\hline
\end{tabular}

Bron: CBS

Voor Economie en Administratie en Handel en Ondernemerschap, zien we een gelijkaardig beeld. Bij het eerste domein varieert het percentage dat minimaal 12 uur werkzaam is tussen $51 \%$ en $80 \%$, bij het tweede domein tussen $55 \%$ en $78 \%$. Het gaat in beide gevallen respectievelijk om niveau 2 en niveau 4 van de bol-opleiding. Algemeen, kunnen we opmerken dat het aandeel werkzaam verbetert over de niveaus. Tabel S.1 in de statistische bijlage geeft ook de cijfers voor de bbl-opleiding.

Als we dieper ingaan op de onderliggende beroepsopleidingen (zie Tabel 7.2) dan wordt dit beeld bevestigd. In Economie en Administratie varieert het percentage tussen 51\% (ondersteunende administratieve beroepen, niveau 2 bol) en $88 \%$ (financiële dienstverlening, niveau 4 bol), in Handel en Ondernemerschap tussen 56\% (verkoop, niveau 2 bol) en $81 \%$ (ondernemerschap Retail, niveau 4 bol). Ook hier zien we dus een verbetering over de niveaus. Tabel S.2 toont ook de cijfers voor de bbl-beroepsopleidingen.

TABEL 7.2 Aandeel dat minimaal 12 uur werkzaam is: gediplomeerde uitstroom mbo-bol per beroepsopleiding (\%)

\begin{tabular}{|l|r|r|r|}
\hline Beroepsopleiding & Domein & Niveau & Minimaal 12 uur werkzaam \\
\hline Ondersteunende en administratieve beroepen & Economie en Administratie & 2 & 51 \\
\hline Verkoop & Handel en Ondernemerschap & 2 & 56 \\
\hline Commercie & Economie en Administratie & 3 & 71 \\
\hline Financieel administratieve beroepen & Economie en Administratie & 3 & 66 \\
\hline Secretariële beroepen & Economie en Administratie & 3 & 74 \\
\hline Advies en leiding in de verkoop & Handel en Ondernemerschap & 3 & 72 \\
\hline Commercie & & & \\
\hline Financieel administratieve beroepen & Economie en Administratie & 4 & 81 \\
\hline Financiële dienstverlening & Economie en Administratie & 4 & 81 \\
\hline Juridisch-administratieve beroepen & Economie en Administratie & 4 & 88 \\
\hline Secretariële beroepen & Economie en Administratie & 4 & 74 \\
\hline Commercie & Economie en Administratie & 4 & 84 \\
\hline Management Retail & Handel en Ondernemerschap & 4 & n.b. \\
\hline Ondernemerschap Retail & Handel en Ondernemerschap & 4 & 79 \\
\hline Bron: BVE-Moniter & Handel en Ondernemerschap & 4 & 81 \\
\hline
\end{tabular}

Bron: BVE-Monitor (2014-2017), ROA/CBS 


\subsection{Arbeidsmarkt van mbo-gediplomeerden: Aanvullende indicatoren}

Op basis van de BVE-Monitor (2014-2017) is het eveneens mogelijk om de arbeidsmarkt van de gediplomeerden van mbo-opleidingen te karakteriseren. Om te beginnen, is het interessant om de werkloosheid een jaar na het behalen van het diploma te analyseren (zie Tabel 7.3) We doen dit wederom voor de gediplomeerden van niveau 2, 3 en 4 afkomstig uit de domeinen Economie en Administratie en Handel en Ondernemerschap, en focussen enkel op de bol-leerweg."

Tabel 7.3 toont dat voor Economie en Administratie het percentage dat werkloos is op basis van de 12 uurs grens tussen 12\% en 29\% ligt, respectievelijk niveau 4 en 2 bol. Voor Handel en Ondernemerschap ligt dit percentage tussen $8 \%$ en $23 \%$, respectievelijk voor dezelfde niveaus. Wat werkloosheid betreft, zien we dus geen al te grote verschillen tussen beide domeinen. Als we echter vergelijken met het gehele mbo, dan zien we dat daar het gemiddelde werkloosheidspercentage (aanzienlijk) lager ligt. Dit geldt in principe voor alle niveaus en leerwegen.

TABEL 7.3 Werkloosheid op basis van 12 uurs grens (\%)

\begin{tabular}{|l|r|r|r|}
\hline Domein & Niveau 2 bol & Niveau 3 bol & Niveau 4 bol \\
\hline Economie en Administratie & 29 & 21 & 12 \\
\hline Handel en Ondernemerschap & 23 & 16 & 8 \\
\hline Mbo Totaal & 18 & 12 & 9 \\
\hline
\end{tabular}

Bron: BVE-Monitor (2014-2017), ROA/CBS

Wanneer we focussen op de verschillende beroepsopleidingen binnen de twee domeinen, dan neemt de variatie toe (zie Tabel 7.4). Bij Economie en Administratie ligt het percentage dat werkloos is op basis van de 12 uurs grens tussen $8 \%$ (commercie, niveau 3 bol) en $28 \%$ (ondersteunende administratieve beroepen, niveau 2 bol). Voor Handel en Ondernemerschap ligt dit tussen 6\% (commercie, niveau 4 bol) en 22\% (verkoop, niveau 2 bol). Voor beide domeinen geldt dat de hogere werkloosheidscijfers te vinden zijn bij de lagere mbo-niveaus. Voor de bbl-beroepsopleidingen verwijzen we naar tabel S.3 in de statistische bijlage.

11 De cijfers voor de bbl-opleidingen zijn te vinden in de tabellen in de statistische bijlage. 
TABEL 7.4 Gediplomeerde uitstroom: werkloosheid op basis van 12 uurs grens, per beroepsopleiding (\%)

\begin{tabular}{|l|r|r|r|}
\hline Beroepsopleiding & Niveau & Domein & $\begin{array}{r}\text { Werkloosheid (12 uurs } \\
\text { grens) }\end{array}$ \\
\hline Ondersteunende administratieve beroepen & 2 & Economie en Administratie & 28 \\
\hline Commercie & 3 & Economie en Administratie & 8 \\
\hline Financieel administratieve beroepen & 3 & Economie en Administratie & 26 \\
\hline Secretariële beroepen & 3 & Economie en Administratie & 22 \\
\hline Commercie & 4 & Economie en Administratie & 10 \\
\hline Financieel administratieve beroepen & 4 & Economie en Administratie & 11 \\
\hline Financiële dienstverlening & 4 & Economie en Administratie & 20 \\
\hline Juridisch-administratieve beroepen & 4 & Economie en Administratie & 13 \\
\hline Secretariële beroepen & 4 & Economie en Administratie & 13 \\
\hline Verkoop & & & 22 \\
\hline Advies en leiding in de verkoop & 2 & Handel en Ondernemerschap & 15 \\
\hline Commercie & 3 & Handel en Ondernemerschap & 6 \\
\hline Management en Retail & 4 & Handel en Ondernemerschap & 10 \\
\hline Ondernemerschap Retail & 4 & Handel en Ondernemerschap & 8 \\
\hline Bron: BVE-M
\end{tabular}

Bron: BVE-Monitor (2014-2017), ROA/CBS

In het kader van de beleidsregel arbeidsmarktrelevantie wordt werkloosheid berekend op basis van de vraag of een gediplomeerde minimaal 12 uur per week werkzaam is of niet. Internationaal, en sinds 2015 ook in Nederlandse statistieken van onder andere het CBS, wordt echter een 1 uurs grens gehanteerd. Met andere woorden, gediplomeerden die 2 uur per week werkzaam zijn worden als werkzame beroepsbevolking geclassificeerd, onafhankelijk van de vraag of zij tegelijkertijd op zoek zijn naar ander werk. Hanteren we de 1 uurs grens voor werkloosheid, dan liggen de werkloosheidspercentages inderdaad lager.

Werk vinden is natuurlijk stap een van de arbeidsmarktintrede. Werk vinden dat bij de gevolgde opleiding past, is voor de gediplomeerden ten minste zo belangrijk. Op basis van de BVE-Monitor kan aan de hand van een tweetal indicatoren, nader vastgesteld worden in hoeverre het gevonden werk past bij de afgeronde opleiding; werk dat qua niveau en inhoud aansluit bij de gevolgde opleiding.

Tabel 7.5 laat zien dat voor Economie en Administratie, het percentage werkende gediplomeerden dat een functie heeft gevonden die qua niveau minimaal bij de afgeronde mboopleiding past, tussen 59\% en 75\% ligt. Voor het domein Handel en Ondernemerschap liggen de percentages lager, namelijk tussen $55 \%$ en $63 \%$. Vergelijken we de percentages van de twee onderscheiden mbo-domeinen met de gemiddelde waarden voor het mbo, dan zien we dat voor de mbo bol, en met name voor Handel en Ondernemerschap, de situatie minder rooskleurig is. 
TABEL 7.5 Werkzaam op minimaal eigen niveau (\%)

\begin{tabular}{|l|r|r|r|}
\hline Domein & Niveau 2 bol & Niveau 3 bol & Niveau 4 bol \\
\hline Economie en Administratie & 59 & 65 & 75 \\
\hline Handel en Ondernemerschap & 55 & 54 & 63 \\
\hline Mbo Totaal & 66 & 70 & 78 \\
\hline
\end{tabular}

Werkzaam $=$ werkzaam voor minimaal 12 uur per week.

Bron: BVE-Monitor (2014-2017), ROA/CBS

Nadere analyses (zie Tabel 7.6) laten zien dat binnen het domein Economie en Administratie de beroepsopleiding commercie op niveau 3 bol het slechtst scoort (50\%), en financiële dienstverlening en secretariële beroepen op niveau 4 het best (beiden 85\%). Voor Handel en Ondernemerschap zijn dit respectievelijk management Retail op niveau 4 (53\%) en commercie op niveau 4 (72\%). Tabel S.3 geeft de cijfers voor de bblopleidingen.

TABEL 7.6 Gediplomeerde uitstroom: werkzaam op minimaal eigen niveau, per beroepsopleiding (\%)

\begin{tabular}{|l|r|r|r|}
\hline Beroepsopleiding & Niveau & Domein & Op niveau werkzaam \\
\hline Ondersteunende administratieve beroepen & 2 & Economie en Administratie & 59 \\
\hline Commercie & 3 & Economie en Administratie & 50 \\
\hline Financieel administratieve beroepen & 3 & Economie en Administratie & 67 \\
\hline Secretariële beroepen & 3 & Economie en Administratie & 72 \\
\hline Commercie & 4 & Economie en Administratie & 81 \\
\hline Financieel administratieve beroepen & 4 & Economie en Administratie & 74 \\
\hline Financiële dienstverlening & 4 & Economie en Administratie & 85 \\
\hline Juridisch-administratieve beroepen & 4 & Economie en Administratie & 76 \\
\hline Secretariële beroepen & 4 & Economie en Administratie & 85 \\
\hline Verkoop & & & \\
\hline Advies en leiding in de verkoop & 2 & Handel en Ondernemerschap & 55 \\
\hline Commercie & 3 & Handel en Ondernemerschap & 55 \\
\hline Management Retail & 4 & Handel en Ondernemerschap & 72 \\
\hline Ondernemerschap Retail & 4 & Handel en Ondernemerschap & 53 \\
\hline
\end{tabular}

Werkzaam $=$ werkzaam voor minimaal 12 uur per week.

Bron: BVE-Monitor (2014-2017), ROA/CBS

Wat de aansluiting qua inhoud betreft, in andere woorden de vraag of de richting van het gevonden werk bij de studierichting past, liggen de percentages werkzame gediplomeerden die binnen het eigen domein werken voor het domein Economie en Administratie tussen de $38 \%$ en $54 \%$ en voor Handel en Ondernemerschap tussen $43 \%$ en 47\% (zie Tabel 7.7). 
TABEL 7.7 Werkzaam binnen eigen opleidingsdomein (\%)

\begin{tabular}{|l|r|r|r|}
\hline Domein & Niveau 2 bol & Niveau 3 bol & Niveau 4 bol \\
\hline Economie en Administratie & 38 & 47 & 54 \\
\hline Handel en Ondernemerschap & 44 & 47 & 43 \\
\hline Mbo Totaal & 59 & 65 & 67 \\
\hline
\end{tabular}

Werkzaam $=$ werkzaam voor minimaal 12 uur per week.

Bron: BVE-Monitor (2014-2017), ROA/CBS

Tabel 7.8 toont dat voor Economie en Administratie de verschillen groot zijn tussen de verschillende beroepsopleidingen; $30 \%$ vs. $68 \%$ (commercie niveau 3 bol vs. secretariële beroepen niveau 4 bol). Voor Handel en Ondernemerschap liggen deze percentages veel dichter bij elkaar, namelijk 38\% vs. $48 \%$ (management Retail niveau 4 bol vs. advies en leiding in de verkoop niveau 4 bol). Tabel S.3 geeft de cijfers voor de bbl-opleidingen.

TABEL 7.8 Gediplomeerde uitstroom: werkzaam binnen eigen opleidingsdomein, per beroepsopleiding (\%)

\begin{tabular}{|l|r|r|r|}
\hline Beroepsopleiding & Niveau & Domein & $\begin{array}{r}\text { Binnen eigen domein } \\
\text { werkzaam }\end{array}$ \\
\hline Ondersteunende administratieve beroepen & 2 & Economie en Administratie & 36 \\
\hline Commercie & 3 & Economie en Administratie & 30 \\
\hline Financieel administratieve beroepen & 3 & Economie en Administratie & 47 \\
\hline Secretariële beroepen & 3 & Economie en Administratie & 59 \\
\hline Commercie & 4 & Economie en Administratie & 53 \\
\hline Financieel administratieve beroepen & 4 & Economie en Administratie & 64 \\
\hline Financiële dienstverlening & 4 & Economie en Administratie & 66 \\
\hline Juridisch-administratieve beroepen & 4 & Economie en Administratie & 46 \\
\hline Secretariële beroepen & 4 & Economie en Administratie & 68 \\
\hline Verkoop & & & 45 \\
\hline Advies en leiding in de verkoop & 2 & Handel en Ondernemerschap & 48 \\
\hline Commercie & 3 & Handel en Ondernemerschap & 41 \\
\hline Management Retail & 4 & Handel en Ondernemerschap & 38 \\
\hline Ondernemerschap Retail & 4 & Handel en Ondernemerschap & 43 \\
\hline Verkzan & 4 & Handel en Ondernemerschap & \\
\hline
\end{tabular}

Werkzaam $=$ werkzaam voor minimaal 12 uur per week.

Bron: BVE-Monitor (2014-2017), ROA/CBS

Ten slotte bespreken we in Tabel 7.9 het aandeel dat spijt heeft van zijn opleidingskeuze en achteraf niet dezelfde opleiding zou kiezen. Hier liggen de percentages voor Economie en Administratie tussen 24\% en 38\% en bij Handel en Ondernemerschap tussen $34 \%$ en $43 \%$. 
TABEL 7.9 Aandeel dat spijt heeft (\%)

\begin{tabular}{|l|r|r|r|}
\hline Domein & Niveau 2 bol & Niveau 3 bol & Niveau 4 bol \\
\hline Economie en Administratie & 38 & 35 & 24 \\
\hline Handel en Ondernemerschap & 39 & 43 & 34 \\
\hline Mbo Totaal & 35 & 31 & 24 \\
\hline
\end{tabular}

Bron: BVE-Monitor (2014-2017), ROA/CBS

Dit geldt ook als we binnen de domeinen kijken naar de verschillende beroepsopleidingen. Zo ligt dit bij Economie en Administratie tussen 18\% (juridisch-administratieve beroepen, niveau 4 bol) en $40 \%$ (commercie, niveau 3 bol), en bij Handel en Ondernemerschap tussen 32\% (commercie, niveau 4 bol) en $44 \%$ (advies en leiding in de verkoop, niveau 3 bol) (zie Tabel 7.10). Wat opvalt bij Economie en Administratie, is dat het aandeel dat spijt heeft over het algemeen afneemt naarmate men in een hoger niveau zit. Tabel S.3 geeft de cijfers voor de bbl-opleidingen.

TABEL 7.10 Gediplomeerde uitstroom: aandeel dat spijt heeft, per beroepsopleiding (\%)

\begin{tabular}{|l|r|r|r|}
\hline Beroepsopleiding & Niveau & Domein & Spijt \\
\hline Ondersteunende administratieve beroepen & 2 & Economie en Administratie & 38 \\
\hline Commercie & 3 & Economie en Administratie & 40 \\
\hline Financieel administratieve beroepen & 3 & Economie en Administratie & 30 \\
\hline Secretariële beroepen & 3 & Economie en Administratie & 38 \\
\hline Commercie & 4 & Economie en Administratie & 23 \\
\hline Financieel administratieve beroepen & 4 & Economie en Administratie & 20 \\
\hline Financiële dienstverlening & 4 & Economie en Administratie & 29 \\
\hline Juridisch-administratieve beroepen & 4 & Economie en Administratie & 18 \\
\hline Secretariële beroepen & 4 & Economie en Administratie & 32 \\
\hline Verkoop & & Handel en Ondernemerschap & 39 \\
\hline Advies en leiding in de verkoop & 2 & Handel en Ondernemerschap & 44 \\
\hline Commercie & 3 & Handel en Ondernemerschap & 32 \\
\hline Management en Retail & 4 & Handel en Ondernemerschap & 39 \\
\hline Ondernemerschap Retail & 4 & Handel en Ondernemerschap & 33 \\
\hline
\end{tabular}

Bron: BVE-Monitor (2014-2017), ROA/CBS 
In het voorliggende rapport beschrijven we vooral de arbeidsmarktkansen van de gediplomeerde schoolverlaters van het mbo. Echter, jaarlijks verlaat nog steeds een flinke groep jongeren het mbo zonder startkwalificatie. In het schooljaar 2017-2018 verliet 4,9\% van de ruim 380.000 deelnemers van niveau 2-4 het mbo als voortijdig schoolverlaters. Vanuit het domein Handel en Ondernemerschap was dit zelfs 7,4\%. Vanuit het domein Economie en Administratie was het $4,9 \%$. In deze box staan we kort stil bij de meest voorkomende redenen waarom leerlingen van de mbo-domeinen Economie en Administratie en Handel en Ondernemerschap de opleiding zonder diploma verlaten en kijken we naar hun kansen op de arbeidsmarkt. We doen dit op basis van de VSV-Monitor 2017, het onderzoek onder de jongeren die in het schooljaar 2015-2016 de opleiding zonder diploma hebben verlaten en welke ook niet in het bezit zijn van een (eerder behaalde) startkwalificatie. Gezien het aantal respondenten in de VSV-Monitor het niet toelaat om voor de onderscheiden mbo-domeinen ook nog een uitsplitsing naar niveau van de opleiding door te voeren, presenteren we de resultaten onafhankelijk van het mbo-niveau of de mbo leerweg waarin de leerlingen de opleiding volgden.

Tabel B7.1 presenteert de geclusterde hoofdredenen voor het verlaten van de opleiding. Meest voorkomend zijn bij beide domeinen'school-gerelateerde' redenen. Dit cluster omvat redenen zoals 'opleiding was inhoudelijk toch niet wat ik wilde', 'de opleiding was te moeilijk', maar ook 'de opleiding was slecht georganiseerd' of 'problemen met leraren of andere leerlingen'. Onder de voortijdig schoolverlaters van het domein Economie en Administratie vinden we op de tweede plaats (geestelijke) gezondheidsproblemen als de meest belangrijke reden en op de derde plaats persoonlijke problemen. Onder persoonlijke problemen vallen vooral relatieproblemen, echtscheidingen van de ouders of de combinatie van zwangerschap met het volgen van de opleiding. Onder de leerlingen van het domein Handel en Ondernemerschap speelt de arbeidsmarkt ('ik wilde liever gaan werken' of 'ik had een inkomen nodig') de één na belangrijkste reden gevolgd door (geestelijke) gezondheidsproblemen en persoonlijke problemen.

TABEL B7.1 Redenen voor verlaten van mbo opleiding

\begin{tabular}{|l|r|r|r|} 
& $\begin{array}{r}\text { Economie en } \\
\text { Administratie }\end{array}$ & $\begin{array}{r}\text { Handel en } \\
\text { Ondernemerschap }\end{array}$ & MBO totaal \\
\hline School-gerelateerde redenen & 52 & 40 & 54 \\
\hline (Geestelijke) gezondheidsproblemen & 21 & 17 & 21 \\
\hline Persoonlijke problemen & 15 & 13 & 10 \\
\hline Arbeidsmarkt & 8 & 20 & 11 \\
\hline Andere redenen & 4 & 10 & 4 \\
\hline
\end{tabular}

Bron: VSV-Monitor 2017

Tabel B7.2 laat zien dat van de VSV'ers die zich een jaar na het verlaten van de mbo-opleiding op de arbeidsmarkt aanbieden 13\% (Economie en Administratie) en 15\% (Handel en Ondernemerschap) werkloos is . Van degenen die wel werk gevonden hebben, is de meerder- 
heid deeltijds, dat wil zeggen voor minder dan 33 uur per week, werkzaam en vindt slechts één op de drie de aansluiting tussen de afgebroken opleidingen en het gevonden werk voldoende of goed.

TABEL B7.2 Arbeidsmarkt van VSV'ers

\begin{tabular}{|l|r|r|r|} 
& $\begin{array}{r}\text { Economie en } \\
\text { Administratie }\end{array}$ & $\begin{array}{r}\text { Handel en } \\
\text { Ondernemerschap }\end{array}$ & MBO totaal \\
\hline \% Werkloosheid & 13 & 15 & 16 \\
\hline \% voldoende/goede aansluiting & 34 & 35 & 35 \\
\hline \% voltijdbaan & 30 & 36 & 43 \\
\hline
\end{tabular}

Bron: VSV-Monitor 2017

Tot slot laat de VSV-Monitor zien dat $42 \%$ van de VSV'ers afkomstig van het domein Economie en Administratie en 38\% van de VSV-ers afkomstig van het domein Handel en Ondernemerschap geen spijt heeft van het vroegtijdig verlaten van de opleiding. Met andere woorden, de meerderheid van de voortijdig schoolverlaters heeft spijt. Echter, nadere analyses laten zien dat een duidelijke meerderheid van degenen die spijt hebben aangeven dat ze destijds niet anders konden en slechts 13\% (Economie en Administratie) en 18\% (Handel en Ondernemerschap) aangeeft spijt te hebben en vindt achteraf gezien een foute keuze gemaakt te hebben.

\subsection{Hbo-gediplomeerde leerlingen: HBO-Monitor}

In Hoofdstuk 6 lieten we zien dat het behalen van een mbo-niveau 4 opleiding vaak niet het einde van de onderwijsloopbaan is voor gediplomeerden van de mbo-domeinen Economie en Administratie en Handel en Ondernemerschap. Een flink deel van hen zet hun onderwijsloopbaan in het hbo voort, vaak in de sector Economie. In dit paragraaf staan we kort stil bij de arbeidsmarktkansen van afgestudeerden van deze hbo-sector. Tabel 7.11 vat een viertal indicatoren samen, we onderscheiden daarbij afgestudeerden van voltijdse, deeltijdse en duale bacheloropleidingen.

TABEL 7.11 Arbeidsmarkt afgestudeerden hbo: sector Economie

\begin{tabular}{|l|r|r|r|r|} 
& Werkloosheid & Op niveau & Binnen eigen domein \\
werkzaam & werkzaam & Spijt \\
\hline Voltijd & 7 & 81 & 66 & 30 \\
\hline Deeltijd & 5 & 76 & 69 & 15 \\
\hline Duaal & 2 & 82 & 74 & 22 \\
\hline
\end{tabular}

Werkloosheid op basis van 12 uur grens / Op niveau werkzaam indien minimaal 12 uur werkzaam / Binnen eigen domein werkzaam indien minimaal 12 uur werkzaam.

Bron: HBO-Monitor 2014-2017

De duale opleiding scoort het best op drie van de vier vlakken, terwijl de voltijdse opleiding het slechts scoort op drie van de vier vlakken. Wat werkloosheid betreft, is dit bij 
de duale opleiding slechts $2 \%$, terwijl dit voor de voltijdse opleiding $7 \%$ is. Het aandeel dat op het eigen niveau werkzaam is, is vergelijkbaar voor de voltijdse en de duale opleiding, respectievelijk $81 \%$ en $82 \%$, en is voor de deeltijdse opleiding $76 \%$. Het aandeel dat binnen het eigen domein werkzaam is, varieert tussen $66 \%$ en $74 \%$, respectievelijk voor de voltijdse en duale opleiding. De zichtbare verschillen tussen de voltijdse en duale opleiding (en in mindere mate tussen de voltijdse en deeltijdse variant) kunnen in de regel verklaard worden doordat in de laatstgenoemde opleiding werken een centrale rol krijgt tijdens de studie. Duale studenten werken tijdens de opleiding al op hbo-niveau en in het eigen domein en dienen dan ook in tegenstelling tot de voltijdse studenten op moment van het behalen van het diploma niet op zoek te gaan naar een functie. Tot slot laat Tabel 7.11 zien dat van de gediplomeerden die de voltijdse bacheloropleiding hebben afgerond, bijna een op de drie achteraf spijt heeft van de gevolgde opleiding.

\subsection{Arbeidsmarktprognoses}

Paragraaf 7.1 tot en met 7.3 hebben de arbeidsmarktkansen van mbo- en hbo-gediplomeerden voor de periode 2014-2017 in beeld gebracht. In deze afsluitende paragraaf kijken we op basis van arbeidsmarktprognoses voor een aantal opleidingstypes naar de situatie tot 2022. We doen dit aan de hand van een viertal indicatoren:

Verwachte uitbreidingsvraag tot 2022: "Vraag naar nieuwe arbeidskrachten die ontstaat door groei van de werkgelegenheid. Als er sprake is van een werkgelegenheidsdaling, is de uitbreidingsvraag negatief." (ROA/POA, 2018)

Verwachte vervangingsvraag tot 2022: "Vervangingsvraag is de vraag naar nieuwe arbeidskrachten die ontstaat door bijvoorbeeld pensionering, (tijdelijke) uittreding vanwege zorgtaken, arbeidsongeschiktheid, beroepsmobiliteit of doorstroom naar andere opleiding." (ROA/POA, 2018)

Verwachte baanopeningen tot 2022:"Baanopeningen zijn de totale vraag naar nieuwkomers op de arbeidsmarkt. Deze is gebaseerd op de verwachte uitstroom van schoolverlaters uit het initiële dag-, deeltijd-, niet-reguliere voltijdonderwijs en de beroepsgerichte volwasseneneducatie." (ROA/POA, 2018)

ITA toekomstige arbeidsmarktsituatie in 2022: "Indicator Toekomstige Arbeidsmarktsituatie (ITA) in 2022. Naarmate de waarde van de ITA hoger ligt, is er sprake van een slechter arbeidsmarktperspectief. Een waarde tussen 1.01 en 1.05 duidt op een evenwichtssituatie." (ROA/POA, 2018) 
TABEL 7.12 Arbeidsmarktprognoses tot 2022

\begin{tabular}{|c|c|c|c|c|}
\hline Opleidingstype & $\begin{array}{r}\text { Verwachte } \\
\text { uitbreidingsvraag (aantal } \\
\text { en typering) }\end{array}$ & $\begin{array}{r}\text { Verwachte } \\
\text { vervangingsvraag } \\
\text { (aantal en typering) }\end{array}$ & $\begin{array}{r}\text { Verwachte } \\
\text { baanopeningen } \\
\text { (aantal en typering) }\end{array}$ & $\begin{array}{r}\text { Toekomstige } \\
\text { arbeidsmarktsituatie } \\
\text { (waarde en typering) }\end{array}$ \\
\hline \multirow{3}{*}{$\begin{array}{l}\text { mbo } 2 / 3 \text { commercieel, } \\
\text { financieel en administratief }\end{array}$} & 2.100 & 19.300 & 21.400 & 1,02 \\
\hline & erg laag & hoog & gemiddeld & redelijk \\
\hline & 4.400 & 12.300 & 16.700 & 1,27 \\
\hline \multirow[t]{2}{*}{ mbo $2 / 3$ detailhandel } & laag & gemiddeld & laag & slecht \\
\hline & 3.500 & 14.200 & 17.700 & 1,02 \\
\hline \multirow[t]{2}{*}{ mbo $2 / 3$ secretarieel } & laag & gemiddeld & laag & redelijk \\
\hline & 2.500 & 9.600 & 12.100 & 1,04 \\
\hline \multirow[t]{2}{*}{ mbo 2/3 informatica } & gemiddeld & hoog & hoog & redelijk \\
\hline & 2.600 & 5.200 & 7.900 & 1,22 \\
\hline \multirow{4}{*}{$\begin{array}{l}\text { mbo } 2 / 3 \text { horeca } \\
\text { mbo } 2 / 3 \text { recreatie, vrijetijd } \\
\text { en sport }\end{array}$} & laag & laag & erg laag & slecht \\
\hline & 1.300 & 3.100 & 4.400 & 1,41 \\
\hline & gemiddeld & laag & gemiddeld & slecht \\
\hline & 1.100 & 4.300 & 5.400 & 0,9 \\
\hline \multirow{2}{*}{$\begin{array}{l}\text { mbo } 2 / 3 \text { facilitaire } \\
\text { dienstverlening }\end{array}$} & gemiddeld & hoog & hoog & goed \\
\hline & 3.600 & 8.900 & 12.500 & 1,16 \\
\hline mbo $2 / 3$ veiligheid & gemiddeld & gemiddeld & gemiddeld & slecht \\
\hline \multirow{3}{*}{$\begin{array}{l}\text { mbo } 4 \text { commercieel, } \\
\text { financieel en administratief }\end{array}$} & 3.300 & 20.400 & 23.700 & 1,07 \\
\hline & erg laag & gemiddeld & laag & matig \\
\hline & 5.100 & 13.400 & 18.500 & 1,11 \\
\hline \multirow[t]{2}{*}{ mbo 4 detailhandel } & laag & laag & laag & matig \\
\hline & 2.900 & 21.500 & 24.400 & 1,06 \\
\hline \multirow[t]{2}{*}{ mbo 4 secretarieel } & erg laag & gemiddeld & laag & matig \\
\hline & 2.800 & 2.000 & 4.800 & 1,25 \\
\hline \multirow[t]{2}{*}{ mbo 4 informatica } & erg hoog & Erg laag & laag & slecht \\
\hline & 2.300 & 3.300 & 5.600 & 1,17 \\
\hline \multirow[t]{2}{*}{ mbo 4 horeca } & gemiddeld & erg laag & erg laag & slecht \\
\hline & 2.300 & 2.000 & 4.200 & 1,27 \\
\hline $\begin{array}{l}\text { mbo } 4 \text { recreatie, vrijetijd } \\
\text { en sport }\end{array}$ & gemiddeld & erg laag & erg laag & slecht \\
\hline \multirow{2}{*}{$\begin{array}{l}\text { mbo } 4 \text { facilitaire } \\
\text { dienstverlening }\end{array}$} & 1.000 & 2.800 & 3.800 & 1,01 \\
\hline & gemiddeld & gemiddeld & gemiddeld & redelijk \\
\hline
\end{tabular}


TABEL 7.12 Arbeidsmarktprognoses tot 2022 (vervolg)

\begin{tabular}{|l|r|r|r|r|}
\hline & 3.800 & 9.500 & 13.400 & 1,14 \\
\hline hbo bedrijfseconomie & gemiddeld & laag & laag & matig \\
\hline hbo marketing en & 5.900 & 9.600 & 15.500 & 1,14 \\
\hline commerciële economie & gemiddeld & laag & erg laag & matig \\
\hline hbo accountancy en & 2.700 & 9.200 & 11.900 & 1,03 \\
\hline financiën & laag & gemiddeld & gemiddeld & redelijk \\
\hline & 10.500 & 20.300 & 30.800 & 1,09 \\
\hline hbo bedrijfskunde en hrm & laag & laag & erg laag & matig \\
\hline & 1.800 & 3.400 & 5.200 & 1,19 \\
\hline hbo recht & laag & erg laag & erg laag & slecht \\
\hline hbo hotel, vrijetijd en & 5.300 & 6.200 & 11.500 & 1,18 \\
facility management & gemiddeld & erg laag & erg laag & slecht \\
\hline
\end{tabular}

\section{Bron: AIS, ROA}

Tabel 7.12 geeft per opleiding de waarde van de indicator en de kwalitatieve typering. Het beeld dat we in eerste instantie krijgen is duidelijk. Over het algemeen, zijn de verwachte uitbreidingsvraag, de verwachte vervangingsvraag en het verwacht aantal baanopeningen aan de lage kant, met uitzondering van een aantal opleidingen, namelijk mbo $2 / 3$ commercieel, financieel en administratief (verwachte vervangingsvraag is hoog). Dit beeld wordt weerspiegeld in de waarde van de ITA-indicator, die varieert tussen 1,27 ( $m$ bo 2/3 detailhandel) en 1,02 (mbo 2/3 commercieel, financieel en administratief) en mbo $2 / 3$ secretarieel). Dit wijst op een slecht tot matig arbeidsmarktperspectief voor het merendeel van de opleidingen. 


\section{STATISTISCHE BIJLAGE}

TABEL S.1 Aandeel dat minimaal 12 uur werkzaam is: gediplomeerde uitstroom (\%)

\begin{tabular}{|l|r|r|r|}
\hline Domein & Leerweg & Niveau & Minimaal 12 uur werkzaam \\
\hline Economie en Administratie & bol & 2 & 51 \\
\hline Handel en Ondernemerschap & bol & 2 & 55 \\
\hline Economie en Administratie & bbl & 2 & 79 \\
\hline Handel en Ondernemerschap & bbl & 2 & 83 \\
\hline Economie en Administratie & bol & 3 & 70 \\
\hline Handel en Ondernemerschap & bol & 3 & 71 \\
\hline Economie en Administratie & bbl & 3 & 87 \\
\hline Handel en Ondernemerschap & bbl & 3 & 91 \\
\hline Economie en Administratie & & & 80 \\
\hline Handel en Ondernemerschap & bol & 4 & 78 \\
\hline Economie en Administratie & bol & 4 & 92 \\
\hline Handel en Ondernemerschap & bbl & 4 & 95 \\
\hline
\end{tabular}

\section{Bron: CBS}


TABEL S.2 Aandeel dat minimaal 12 uur werkzaam is: gediplomeerde uitstroom, per beroepsopleiding (\%)

\begin{tabular}{|c|c|c|c|c|}
\hline Beroepsopleiding & Domein & Leerweg & Niveau & $\begin{array}{r}\text { Minimaal } 12 \text { uur } \\
\text { werkzaam }\end{array}$ \\
\hline Ondersteunende administratieve beroepen & Economie en Administratie & bol & 2 & 51 \\
\hline Ondersteunende administratieve beroepen & Economie en Administratie & bbl & 2 & 79 \\
\hline Verkoop & Handel en Ondernemerschap & bol & 2 & 56 \\
\hline Verkoop & Handel en Ondernemerschap & bbl & 2 & 83 \\
\hline Commercie & Economie en Administratie & bol & 3 & 71 \\
\hline Financieel administratieve beroepen & Economie en Administratie & bol & 3 & 66 \\
\hline Secretariële beroepen & Economie en Administratie & bol & 3 & 74 \\
\hline Commercie & Economie en Administratie & bbl & 3 & 91 \\
\hline Financieel administratieve beroepen & Economie en Administratie & bbl & 3 & 80 \\
\hline Secretariële beroepen & Economie en Administratie & bbl & 3 & 82 \\
\hline Advies en leiding in de verkoop & Handel en Ondernemerschap & bol & 3 & 72 \\
\hline Advies en leiding in de verkoop & Handel en Ondernemerschap & bbl & 3 & 91 \\
\hline Commercie & Economie en Administratie & bol & 4 & 81 \\
\hline Financieel administratieve beroepen & Economie en Administratie & bol & 4 & 81 \\
\hline Financiële dienstverlening & Economie en Administratie & bol & 4 & 88 \\
\hline Juridisch-administratieve beroepen & Economie en Administratie & bol & 4 & 74 \\
\hline Secretariële beroepen & Economie en Administratie & bol & 4 & 84 \\
\hline Commercie & Economie en Administratie & bbl & 4 & 92 \\
\hline Financieel administratieve beroepen & Economie en Administratie & bbl & 4 & 92 \\
\hline Financiële dienstverlening & Economie en Administratie & bbl & 4 & 92 \\
\hline Juridisch-administratieve beroepen & Economie en Administratie & bbl & 4 & 96 \\
\hline Secretariële beroepen & Economie en Administratie & bbl & 4 & 91 \\
\hline Commercie & Handel en Ondernemerschap & bol & 4 & n.b. \\
\hline Management Retail & Handel en Ondernemerschap & bol & 4 & 79 \\
\hline Ondernemerschap Retail & Handel en Ondernemerschap & bol & 4 & 81 \\
\hline Commercie & Handel en Ondernemerschap & bbl & 4 & n.b. \\
\hline Management Retail & Handel en Ondernemerschap & bbl & 4 & 95 \\
\hline Ondernemerschap Retail & Handel en Ondernemerschap & bbl & 4 & 94 \\
\hline
\end{tabular}

Bron: CBS 


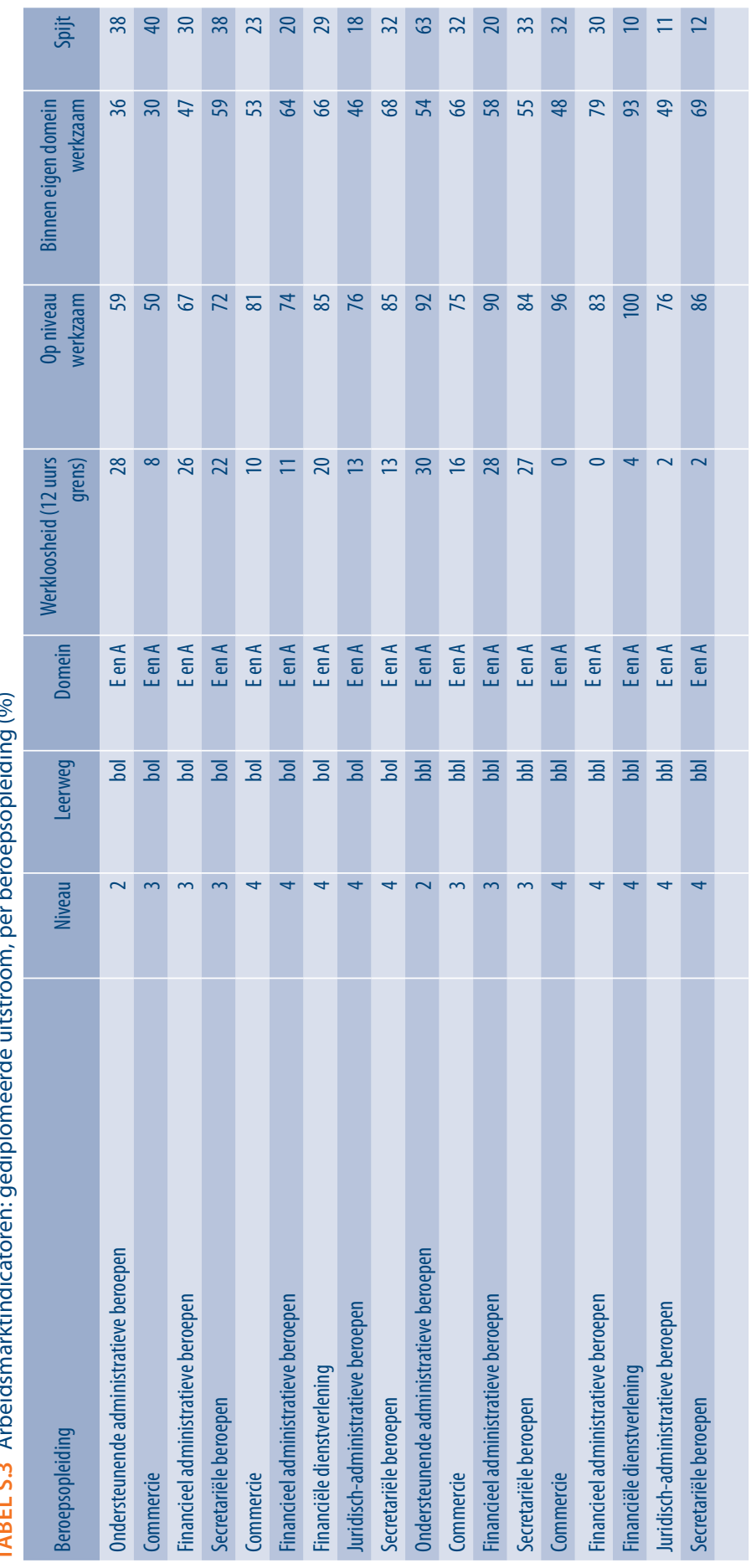




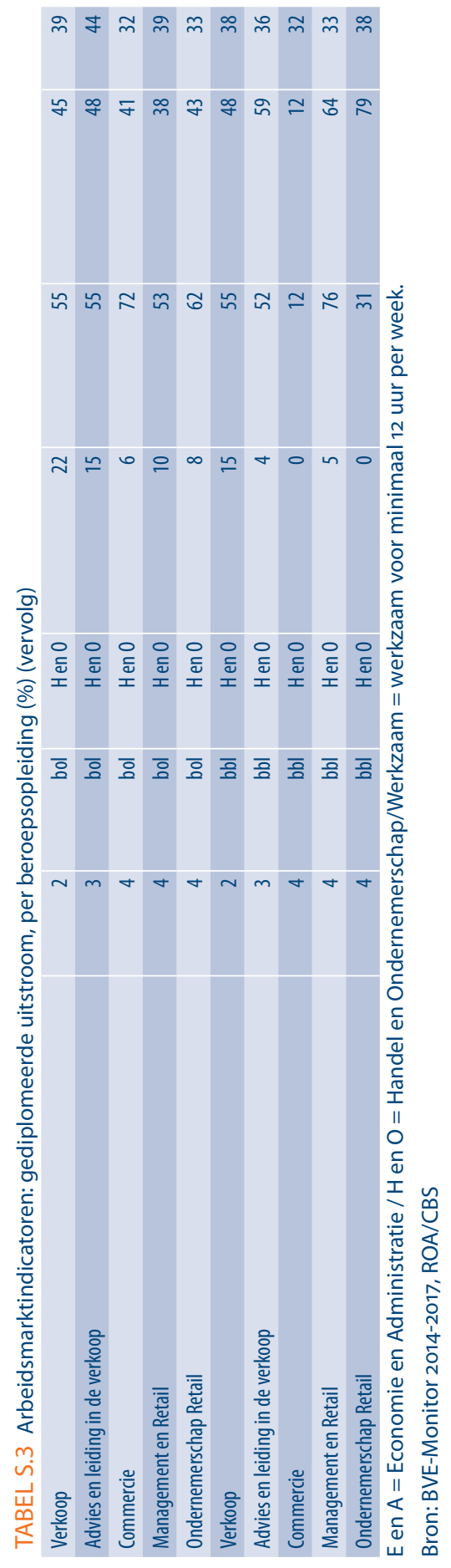

